\title{
BEHAVIOUR OF LI ISOTOPES DURING REGOLITH FORMATION ON GRANITE (MASSIF CENTRAL, FRANCE): CONTROLS ON THE DISSOLVED LOAD IN WATER, SAPROLITE, SOIL AND SEDIMENT
}

\author{
NÉGREL, Ph., MILLOT, R. \\ BRGM, Laboratories Division, Orléans, France -- p.negrel@brgm.fr,
}

\section{Abstract}

Lithium ( $\mathrm{Li}$ ) contents and isotopes were studied in all environments of a small river catchment draining granite in the Margeride mountains of the French Massif Central. This covered surface waters, primary and accessory minerals of the granites, the whole rock, and soil and sediment samples developed in the catchment, completed with regional data for mineral waters and rainwater. The integrated investigation aimed at evaluating the potential of $\mathrm{Li}$ isotopes as effective tracers of water/rock interaction processes within a granitic environment. The $\delta^{7} \mathrm{Li}$ values and $\mathrm{Li}$ concentrations were measured on sediment- and soil samples, following standard acid-dissolution procedures and chemical purification of Li using the cationic exchange resin protocol in a clean lab. Lithium-isotope compositions were measured with a Neptune MC-ICP-MS and Li concentrations by ICP-MS. The samples represented different stages of granite weathering, including fresh granite, weathered-rock, surface saprolite, and sediments in riverbanks and fields bordering the streams. The extent of Li mobility during granite weathering was first evaluated through determining the percentage change relative to $\mathrm{Ti}$, with a range from -31 to $-66 \%$ in the collected samples. The weathered-rock was depleted by $-47 \%$ for $\mathrm{Li}$ with negative $\delta^{7} \mathrm{Li}$ values ranging from -1.9 to $-3.4 \%$ o. Soil to riverbank sediment samples were characterized by less negative $\delta^{7} \mathrm{Li}$ values, indicating that $\mathrm{Li}$ is enriched in soil with fractionation of $\mathrm{Li}$ isotopes and changes of the mineral abundance in the samples. To complement this first view, we i) Modelled the theoretical Li isotope signature of water interacting with granite, using a weathering model based on dissolution; ii) Applied an atmospheric-input correction to surface waters; iii) Applied a Raleigh equation for modelling the Li isotope fractionation when compared with corrected surface water and mineral water; and iv) Compared $\mathrm{Li}$ isotopes with $\mathrm{Sr}$-isotope data in a larger weathering framework.

Keywords: weathering, isotopes, lithium, groundwater, soil, sediment, granite 


\section{1 - Introduction}

Continental silicate weathering is one of the major processes controlling the chemical evolution of the Earth's surface (Gaillardet et al., 1999), because crystalline basement rocks represent over $50 \%$ of the earth's terrestrial surface (Amiotte Suchet et al., 2003). Weathering leads to the formation of unconsolidated alterite or saprolite, usually representing a thickness of up to several tens of metres (Velbel, 1988). The study of alteration processes combines the use of several tools, such as geochemistry (e.g., Nesbitt and Markovics, 1980), isotopic tracing (e.g., Négrel et al., 2018), mineralogy (e.g., Braga et al., 2002), and the notions of space and scale, ranging from a small watershed (White and Blum, 1995; Ackerer et al., 2016) to continental river basins like the Amazon, Ganges or Congo basins (Gaillardet et al., 1999; Abbas and Subramanian, 1984; Négrel et al., 1993).

The links and relationships between weathering, development of saprolite on hill slopes and large-scale dissolved-load transport by streams are very complex. Despite the existence of numerous tools for studying weathering processes (e.g., isotopes of $\mathrm{Sr}, \mathrm{U}$, etc.), the increasing need for proxies has underpinned the development of chemical—such as rare earth elementsand isotopic tools, such as lithium and, more recently, silicon, calcium and magnesium (see Sullivan et al., 2016, for synthesis).

Lithium has two stable isotopes of mass 6 and 7, with natural abundances of $7.5 \%$ and $92.5 \%$, respectively; it is a mobile element that tends to incorporate into the fluid phase during water/rock interactions. The relative mass difference between the two isotopes is considerable at $17 \%$, generating significant mass-dependant fractionation during geochemical processes. Tomascak (2004) noted that the range of variation in lithium-isotope compositions is over 50\%o in geological materials. Silicate rocks have Li-isotope compositions ranging from -2 to $+10 \%$ o (Coplen et al., 2002; Teng et al., 2004). The Li isotope of seawater is about $+31 \%$ (Millot et al., 2004); river water has a large range (-6.0 to $+32.2 \%$, Huh et al., 1998); and (saline) thermo- 
mineral water generally has isotopic compositions of 0 to $+15 \%$ (Millot and Négrel, 2007; Millot et al., 2010b).

In the context of water/rock interactions, numerous studies have clearly shown that $\mathrm{Li}$ isotopes are a promising proxy for tracing silicate weathering reactions (e.g. Huh et al., 1998, 2001; Pistiner and Henderson, 2003; Kisakurek et al., 2004; Rudnick et al., 2004; Pogge von Strandmann et al., 2012; Millot et al., 2007, 2010a, 2010b; Vigier et al., 2009; Wang et al., 2015; Clergue et al. 2015). Silicate minerals host Li and chemical weathering induces isotopic fractionation. This results in enrichment of the heavy isotope $\left({ }^{7} \mathrm{Li}\right)$ in solution, the light isotope $\left({ }^{6} \mathrm{Li}\right)$ being preferentially retained in secondary weathering mineral phases (Huh et al., 2004; Vigier et al., 2008; Weynell et al., 2017), similar to other non-traditional stable-isotope systems such as Ca, Fe and B (Sullivan et al., 2016). Today, lithium isotopes are applied to a wide range of geochemical processes, such as weathering (Pistiner and Henderson, 2003; Huh et al., 2004; Hathorne and James, 2006; Lemarchand et al., 2010; Wanner et al., 2017; Wimpenny et al., 2010; Ryu et al., 2015; Pogge von Strandmann et al., 2019). Other applications are to the study of erosion processes, either in large river-basin studies (Huh et al., 1998, 2001; Kisakurek et al., 2005; Millot et al., 2010a; Dellinger et al., 2015; Henchiri et al., 2014; 2016; Wang et al., 2015; Murphy et al., 2019), or in smaller streams (Vigier et al., 2009; Pogge von Strandmann et al., 2010; Liu et al., 2015); to studying anthopogenic disturbance in soils (Négrel et al., 2010; Tsai et al., 2014); and as geothermometer proxies in mineral waters (Millot and Négrel, 2007), or for tracing groundwater flowpaths (Négrel et al., 2012; Pogge von Strandmann et al., 2014). However, studies on granitic bedrock and its associated weathering products are very scarce (Rudnick et al., 2004; Lemarchand et al., 2010).

At the basic scale of a watershed, the challenge is to integrate all the reservoirs and parts of the watershed affected by the weathering processes. This has been the case in studies involving classic tools, such as strontium isotopes, but not when working with newly developed 
tools. In this study, we measured lithium and its isotope values in all reservoirs and parts of a catchment draining granite. This included surface- and mineral waters, primary minerals and accessory phases of the granites, the whole rock, and samples of soil and sediment generated within the watershed, completed with additional data for rainwater.

Our study has used Li-isotope data for tracing silicate weathering processes at the basic scale of a watershed, considering all its components. This is a novel approach for Li isotopes, which earlier were partly limited due to the difficulty of collecting and analysing samples from all reservoirs. This systematic work is part of a long-term, wide-ranging and integrated geochemical study covering major and trace elements, $\mathrm{Sr}$ isotopes, $\mathrm{Nd}$ isotopes and rare earth elements, in water, sediment and soil within the Margeride mountains of central France (Négrel, 1999; 2006; Négrel et al., 2000); this also includes incorporation of all relevant outside data, such as on separated minerals and long-term monitoring of rainfall.

Isotopic investigation of weathering products generally provides good information on the chemical reactions taking place during such processes. This is further demonstrated by recent studies on the $\mathrm{Li}$ isotope systematics of silicate-rock weathering, in complement to investigations covering regolith production and the development of weathering profiles (Vázquez et al., 2016; Ackerer et al., 2016).

In order to apply Li isotopes as effective tracers of water/rock interaction processes in a small mono-lithological catchment, the effect of atmospheric input was investigated to correct the lithium values of surface- and mineral waters. This allowed replacing $\mathrm{Li}$ isotopes with $\mathrm{Sr}$ isotopes in a larger weathering framework. We also tested a steady-state weathering model and fractionation process modelling on the Margeride granite-gneiss, prerequisites for our reactivetransport model computer simulations that coupled a large number of chemical reactions with mass transport, a key challenge for the effective use of $\mathrm{Li}$ isotopes as a tool in weathering studies. 


\section{2 - General setting}

111 The granite-gneiss Margeride massif is located in the south of the French Massif Central

112 (Figs. 1a, b). It consists of light and dark granite-gneiss with an average mineral composition

113 of the light facies of 37\% quartz, 30\% oligoclase, $23 \%$ K-feldspar and $10 \%$ biotite, and of $31 \%$

114 quartz, 30\% andesine, 20\% K-feldspar and 19\% biotite in the dark facies (Marchand et al.,

115 1985). The mineralogy and chemistry of Margeride granite and gneiss are similar, although the

116 relative abundance of minerals may fluctuate slightly. The presence of a micaschist unit in the

117 massif is worth noting, composed of quartz, muscovite and biotite. Couturié et al. (1979)

118 reported that the different facies of the Margeride granite ( $323 \pm 12 \mathrm{Ma}$., $\mathrm{Rb}-\mathrm{Sr}$ isochron)

119 resulted from fractional crystallization of a crustal magma in a subhorizontal laccolith. The

120 Desges River, a tributary of the Allier, flows approximately $40 \mathrm{~km}$ between the upper part of

121 the Margeride massif and its confluence with the Allier (Négrel, 1999; Fig. 1b). The watershed

122 covers $89 \mathrm{~km}^{2}$ and ranges in altitude from $1250 \mathrm{~m}$ (headwaters) to $650 \mathrm{~m}$ (outlet); the dense N-

123 S-oriented drainage pattern mainly on the top of the Margeride plateaus receives an average

124 annual precipitation of 1000 to $1200 \mathrm{~mm} / \mathrm{yr}^{-1}$. 


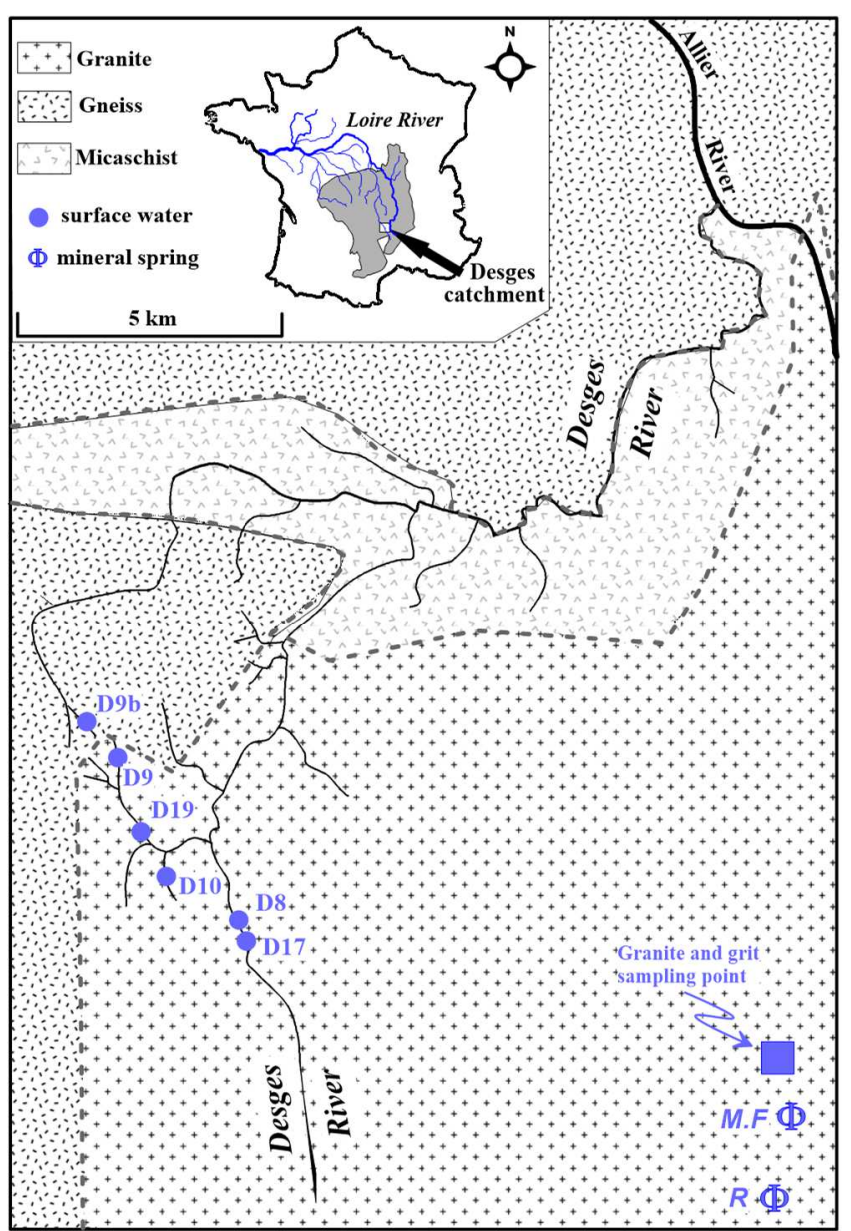

Figure 1. General location map of the Massif Central (in blue-grey), and detailed map of the Desges watershed showing the sampling sites, modified from Négrel (1999; 2006). The main geological units are granite, gneiss, and micaschist. The different sampling points are: bedrock and granitic grit of the Desges watershed, mineral springs (Mazel and Fontaine Basses (M.F) and Ranc (R), surface waters, soils and sediments (Dx).

\section{3 - Material and methods}

In a temperate climate, granite usually weathers into grit (Sequeira Braga et al., 1990; 2002; Le Pera et al., 2001; Paquet and Clauer, 2012). Unweathered bedrock and granitic grit were collected at the same place (Fig. 1, blue square). The Mazel grit sample, collected on top of a granite outcrop, has a fabric skeleton structure retaining the original granitic one, which is commonly observed in the lower $(45-100 \mathrm{~cm}$ depth) part of the soil profile here. Although the texture of the parent rock was largely preserved, the main transformations are chloritization of biotite, kaolinization of plagioclase, and the presence of oxy-hydroxides (Sarazin, 1979). This is reflected in our sample that is mainly composed of quartz (20\%), K-feldspar (20\%), 
140 plagioclase (20\%) and chlorite (5\%), and for which we adopt the classification of Begonha and

141 Sequeira Braga (2002) as "weathered rock".

142 Samples A0, A1 and A2 were collected around station D17, and samples B0, B1 and B2

143 around station D19 (Fig. 1). A0 and B0 (Négrel, 2006), collected from a weathering profile, are

144 not a direct skeleton-fabric material of the granite, but are surface saprolite mainly composed

145 of sand and silt. Samples A1 and B1 are riverbank sediments, classified as sandy-silt. All four

146 samples mainly consist of quartz, K-feldspar, plagioclase and illite-micas, with dramatic

147 changes in relative abundances (Négrel, 2006).

148 The soils in this catchment are podzol and peat, varying in thickness from a few

149 centimetres at the top of the profile to a few metres farther down. They mainly consist of

150 kaolinite, hydroxides and vermiculite, $\mathrm{K}$ feldspar and biotite (isolated from the matrix), and

151 ubiquitous organic and amorphous phases (Bourrié, 1978; Sarazin, 1979). Soil samples A2 and

152 B2, collected in fields bordering the streams, can be classified as silty-sand and contain small

153 amounts of quartz, K-feldspar, plagioclase and illite-micas.

154 The sample-preparation procedure was described in detail by Negrel and Deschamps 155 (1996) and Négrel (1999; 2006). Briefly, weathered rock (Mazel) and surface saprolite (A0 and 156 B0) were powdered, the other soil and sediment samples being oven-dried at $70{ }^{\circ} \mathrm{C}$, 157 homogenized, quartered and dry-sieved through a $165 \mu \mathrm{m}$ nylon mesh, and powdered before 158 analysis. The $\delta^{7} \mathrm{Li}$ values were measured on the sediment- and soil samples following standard 159 acid-dissolution. For rock and sediment, total sample digestion was necessary before separation 160 of Li from the matrix. About $50 \mathrm{mg}$ of crushed sample was dissolved in a closed beaker with 161 an ultrapure mixture of three acids [4 $\mathrm{ml} \mathrm{HF}(23 \mathrm{~N}), 1 \mathrm{ml} \mathrm{HNO} 3(14 \mathrm{~N})$ and $0.1 \mathrm{ml} \mathrm{HClO}_{4}(12 \mathrm{~N})$ ] 162 for four days at $100{ }^{\circ} \mathrm{C}$. After this, once the acid mixture had evaporated, $4 \mathrm{ml}$ of $\mathrm{HCl}(6 \mathrm{~N})$ was 163 added for four days at $100{ }^{\circ} \mathrm{C}$. A sample aliquot (30 $\mathrm{ng}$ of $\mathrm{Li}$ ) of the acid-dissolution residue 
164 was then dissolved in $0.5 \mathrm{ml}$ of $\mathrm{HCl}(0.2 \mathrm{~N})$ before being placed in a column containing cationic

165 resin for Li separation.

Surface-water samples were collected from the river according to the protocol in Négrel

167 (1999); groundwater samples were thermo-mineral waters from naturally flowing springs, taken

168 according to the protocol in Négrel (2006). Briefly, water samples were collected in the field in

169 acid-washed polyethylene bottles after filtration through $0.2 \mu \mathrm{m}$ Sartorius ${ }^{\circledR}$ cellulose acetate

170 filters and then acidified to $\mathrm{pH}<2$, by adding ultra-pure $\mathrm{HNO}_{3}$.

171 Lithium isotopic compositions in soil, sediment and water were measured with a

172 Neptune MC-ICP-MS (see Millot et al., 2004, for details) and Li concentrations with a

173 quadrupole ICP-MS. The ${ }^{7} \mathrm{Li} /{ }^{6} \mathrm{Li}$ values were normalized to the L-SVEC standard solution

174 (NIST SRM 8545) following the standard-sample bracketing method. Typical in-run precision

175 on $\delta^{7} \mathrm{Li}$ determination was about $0.1-0.2 \%$ o $\left(2 \sigma_{\mathrm{m}}\right)$. Chemical separation of lithium from the

176 matrix was achieved before mass analysis following a procedure adapted by Millot et al. (2004),

177 using cationic resin (Bio Rad AG® 50W-X12, 200-400 mesh) and $\mathrm{HCl}(0.2 \mathrm{~N})$ for $30 \mathrm{ng}$ of

178 lithium. Blanks for total chemical extraction were less than 20-30 pg of Li, which is negligible

179 since the blank/sample ratio is less than $10^{-3}$. Accuracy and reproducibility of the total method

180 (purification procedure plus mass analysis) were tested by repeated measurements of a seawater

181 standard (IRMM BCR-403) after separation of Li from the matrix, for which we obtained a

182 mean value of $\delta^{7} \mathrm{Li}=+30.8 \% \_ \pm 0.4(2 \sigma, \mathrm{n}=15)$ over the duration of the analytical period. This

183 mean value agrees with our long-term measurements $\left(\delta^{7} \mathrm{Li}=+31.0 \%\right.$ $\pm 0.5,2 \sigma, \mathrm{n}=30$, Millot et

184 al. 2004) and with other values from the literature.

\section{4 - Results}

186 The Li data ( $\delta^{7} \mathrm{Li}$ and $\mathrm{Li}$ contents) of rock, grit, soil, sediment and separate minerals from the 187 granite and surface and groundwater collected in the catchment are given in Table 1. 


\begin{tabular}{|c|c|c|c|c|c|c|c|}
\hline Sample & Ref. & Li ppm & $\delta 7 \mathrm{Li}$ & Sample & Ref. & $\mathrm{Li}$ & $\delta 7 \mathrm{Li}$ \\
\hline & & & & & & $\mu \mathrm{mol} L-1$ & \\
\hline M1/POU & Whole rock & 143.1 & -1.9 & Spring waters & & & $\delta 7 \mathrm{Li}$ \\
\hline \multirow[t]{2}{*}{ ALT1 } & Mazel grit & 104.7 & -3.4 & Mazel & & 551 & 5.0 \\
\hline & & & & FB1 & & 424 & 4.9 \\
\hline Ap & Apatite & 13.3 & 0.0 & Ranc1 & & 158 & 3.8 \\
\hline PI & Plagioclase & 20.9 & -1.7 & Ranc2 & & 397 & 2.6 \\
\hline $\mathrm{Bi}$ & Biotite & 489.1 & 0.8 & & & & \\
\hline \multirow[t]{2}{*}{$\mathrm{KF}$} & K-Feldspar & 5.3 & -2.6 & Surface waters & & & \\
\hline & & & & D10' & & 0.22 & 12.7 \\
\hline D19-3/A0 & $\mathrm{A} 0$ & 56.2 & 0.1 & D8 & & 0.15 & 9.2 \\
\hline D19-3/A1 & $\mathrm{A} 1$ & 68.8 & -2.1 & D11 & & 0.23 & 12.1 \\
\hline D19-3/A2 & $\mathrm{A} 2$ & 110.9 & -3.4 & D9bis & & 0.16 & 10.0 \\
\hline D17-3/B0 & B0 & 60.6 & 3.3 & D9' & & 0.21 & 10.7 \\
\hline D17-3/B1 & B1 & 61.6 & 0.0 & D11' & & 0.24 & 13.0 \\
\hline D17-3/B2 & B2 & 66.2 & -2.7 & & & & \\
\hline
\end{tabular}

190 Table 1. Results of Li concentration $\left(\mu \mathrm{g} \mathrm{g}^{-1}\right)$ and $\delta^{7}$ Li for parent rock, grit, separate minerals, 191 sediment and soil, expressed in ppm. Results of Li concentration $\left(\mu \mathrm{g} g^{-1}\right)$ and $\delta^{7}$ Li for thermo192 mineral waters (e.g., saline waters cold on surface, but linked to a deep hot reservoir) from 193 Millot and Négrel, 2007; results of Li concentration $\left(\mu \mathrm{mol} l^{-1}\right)$ and $\delta^{7}$ Li for surface waters.

For the separate minerals, Li-rich phases decreased in content from biotite $\left(489 \mu \mathrm{g} \mathrm{g}^{-1}\right)$ apatite, for a $\delta^{7} \mathrm{Li}$ of $-1.9 \%$ in bulk rock. Reconstituting the whole rock from the separate minerals led to a $\mathrm{Li}$ content of $56 \mu \mathrm{g} \mathrm{g}^{-1}$ and a $\delta^{7} \mathrm{Li}$ of $0.45 \%$. These values are inconsistent with the measured ones, implying that the rest of the Li probably occurs in residual minerals with a $\mathrm{Li}$ content of around $86.6 \mu \mathrm{g} \mathrm{g}^{-1}$ and a $\delta^{7} \mathrm{Li}$ of $-3.43 \%$. The Li content in soil and 203 sediment fluctuated from $56 \mu \mathrm{g} \mathrm{g}^{-1}$ (surface saprolite A0) to $111 \mu \mathrm{g} \mathrm{g}^{-1}$ (soil A2). With the 204 exception of soil A2 (almost twice the content in soil B2), the samples had similar Li contents 205 (surface saprolite 56 vs. $61 \mu \mathrm{g} \mathrm{g}^{-1}$; sediment samples $69 v s .62 \mu \mathrm{g} \mathrm{g}^{-1}$ ). Li isotopes in soil and 206 sediment samples ranged from $-3.38 \%$ (soil A2) to $3.31 \%$ (surface saprolite B0). al., 2010a). Li-isotope compositions $\left(\delta^{7} \mathrm{Li}\right)$ varied in the catchment (Table 1), ranging from +9 to $+12 \%$, which is lower than that in other water samples from the Massif Central (Négrel et 
al., 2010) that range from +12 to $+15.1 \%$ o. Lithium-isotope compositions and Li concentrations

213 in the surface waters have a linear relationship $\left(\delta^{7} \mathrm{Li}=5.36 \times \mathrm{Li}+3.73\right)$, with a correlation

214 coefficient $r^{2}=0.81(n=6)$. For groundwater, the lithium concentrations and $\delta^{7} \mathrm{Li}$ were 215 published by Millot et al. (2007): Li concentrations ranged from $157 \mu \mathrm{mol} \mathrm{L}^{-1}$ (Ranc 1) to $216547 \mu \mathrm{mol} \mathrm{L}{ }^{-1}$ (Mazel; their Table 3), which is one order of magnitude higher than in surface 217 water and consistent with their data for thermo-mineral waters in the Massif Central. Lithium218 isotope compositions $\left(\delta^{7} \mathrm{Li}\right)$ in these groundwaters were less variable $(+2.6$ to $+5.0 \%$ ) than in 219 surface waters, with the lowest value observed in Ranc $2(+2.6 \%$ o) and the highest in Mazel $220(+5 \%)$, a range of variation similar to that in thermo-mineral waters of the Massif Central $\left(\delta^{7} \mathrm{Li}\right.$ 221 from +2.6 to $+5.5 \%$, Millot et al., 2007).

\section{5 - Discussion}

\subsection{Mobility of Li during weathering}

224 In order to evaluate the extent of the chemical mobility of Li during granite weathering, we 225 calculated the weathering intensity with $\tau$, the elemental mass transfer coefficient of Brimhall and Dietrich (1987). This calculation avoids the dilution effect and impact of volume change due to weathering (Nesbitt, 1979). We thus calculated the percentage change for Li relative to 228 the immobile element Ti (Clergue et al., 2015) with equation (1), previously used for other elements in the same catchment (Négrel, 2006) and according to Nesbitt (1979):

$$
\tau_{\mathrm{Li}}=100 \times\left(\left[(\mathrm{Li} / \mathrm{Ti})_{\text {sample }} /(\mathrm{Li} / \mathrm{Ti})_{\text {granite }}\right]-1\right)
$$

$232100 \%$ means complete removal of $\mathrm{Li}$ from the parent material. A positive value reflects $\mathrm{Li}$ 233 enrichment by concentration in residual minerals and negative values represent Li depletion, 234 lost from bedrock because of its solubility. However, compared to other soluble elements, less 
depletion of Li may be related to its incorporation into secondary minerals. The percentage

236 change of $\mathrm{Li}$ in the samples, i.e. loss or gain of mobile Li relative to immobile $\mathrm{Ti}\left(\tau_{\mathrm{Li}}\right.$, Fig. 2 ),

237 ranges from -31 to $-66 \%$, the extreme values being for surface-saprolite samples (A0, B0). The 238 grit is depleted around $-47 \%$ compared to bedrock, with a decrease of the $\delta^{7} \mathrm{Li}$ value and a $\mathrm{Li}$ 239 content from $-1.9 \%$ and $143.1 \mu \mathrm{g} \mathrm{g}^{-1}$ in granite to $-3.4 \%$ and $104.7 \mu \mathrm{g} \mathrm{g}^{-1}$ in grit (Fig. 3). The 240 D19 samples show more Li depletion in surface saprolite (A0, -66\%) than in riverbank sediment 241 (A1, -60\%) and soil (A2, -46\%). This depletion is marked by a continuous decrease of $\delta^{7} \mathrm{Li}$ 242 values from $+0.1 \%$ in surface saprolite to $-3.4 \%$ in soil. Compared to the decrease in $\delta^{7} \mathrm{Li}$ 243 values, Li concentration remains constant between samples A0 and A1, and shows an increasing 244 trend in soil sample A2 (Fig. 3), which has the same $\delta^{7} \mathrm{Li}$ and Li-concentration values as those 245 of the grit.

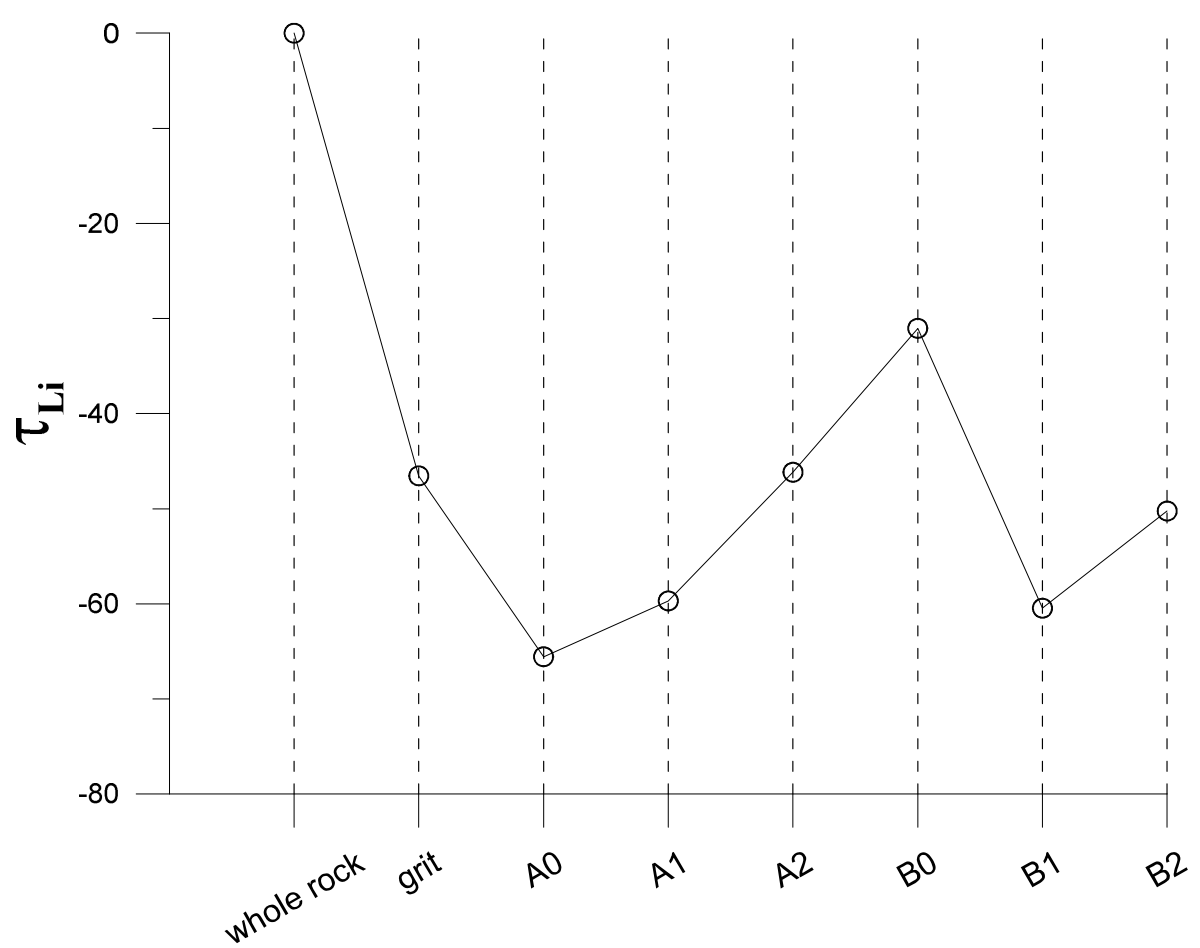

Figure 2. Percentage change of (mobile) Li relative to (immobile) Ti (Equation 1).

The mineralogical composition of the samples was earlier presented in Négrel (2006). 
$251(\sim 20 \%)$ and illite-micas ( 20\%). At station D19, riverbank-sediment sample A1 is quite 252 different, with more quartz (50\%), less feldspars (5\%) and illite-mica around 20\%; it is also 253 richer in chlorite (20\%). Soil sample A2 contains the least quartz (15-20\%); with K-feldspar, 254 illite-micas and plagioclase all around 20\%. This variation is accompanied by more negative $255 \delta^{7} \mathrm{Li}$ values, meaning that $\mathrm{Li}$ is enriched in soil with a fractionation of $\mathrm{Li}$ isotopes and changes 256 in the mineral abundance of the samples (residual minerals have negative $\delta^{7} \mathrm{Li}$; Fig. 3 ). This is 257 accompanied by a change in the Li concentration, with an $18 \%$ increase between A0 and A1, 258 from 56 to $69 \mu \mathrm{g} \mathrm{g}^{-1}$, and a38\% increase between $\mathrm{A} 1$ and $\mathrm{A} 2$, from 69 to $112 \mu \mathrm{g} \mathrm{g}^{-1}$. Between 259 saprolite and soil, the Li concentration increases by $50 \%$.

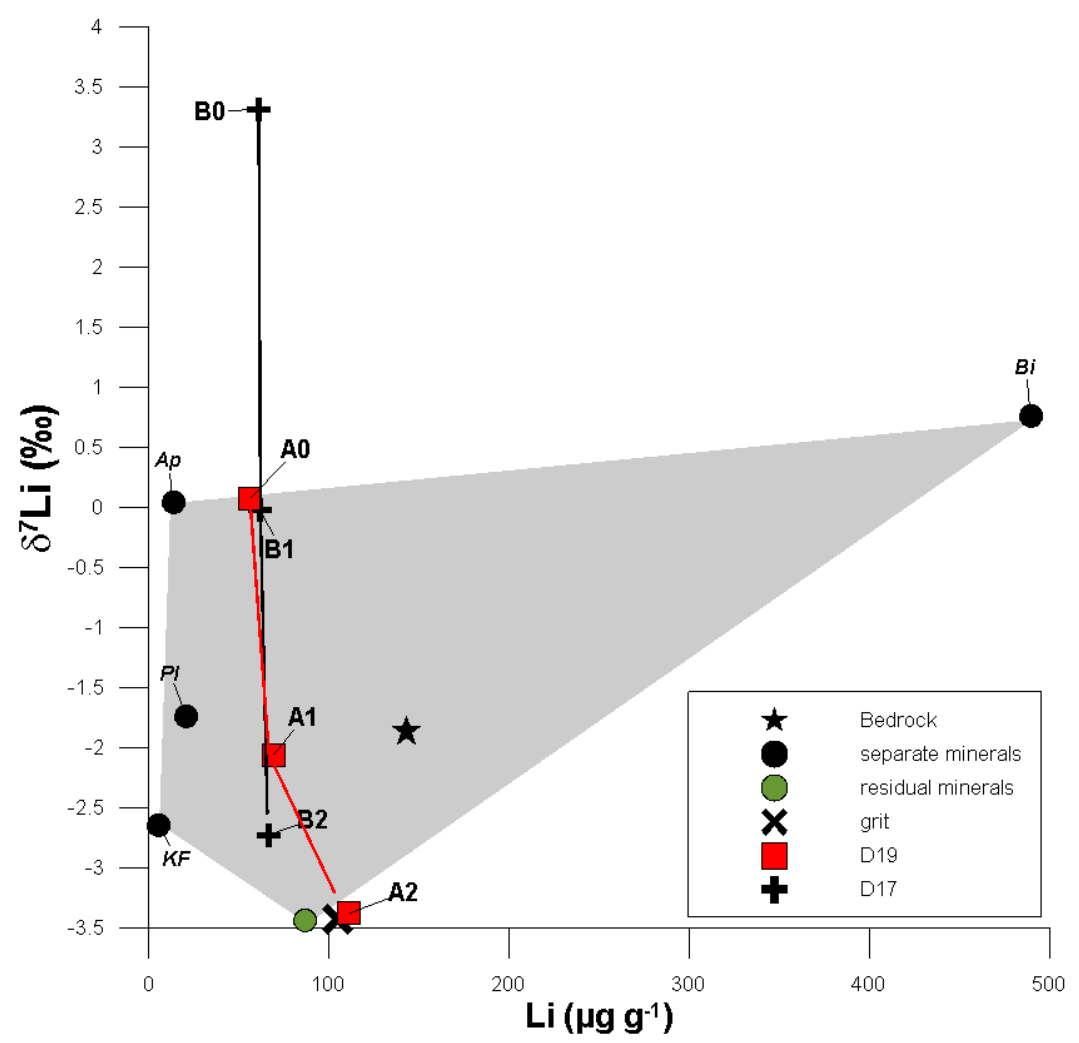

Figure 3. Relationship between $\delta$ Li values (\%o) and Li contents $\left(\mu g g^{-1}\right)$ for bedrock, grit, surface saprolite (AO, B0), riverbank sediments (A1, B1) and soil (A2, B2). The separate minerals from the granite define the greyed area with the addition of residual minerals.

Contrary to station D19, the samples from station D17 show more erratic variations.

266 Surface saprolite B0, depleted around $-31 \%$, has a positive $\delta^{7} \mathrm{Li}$ value of $+3.3 \%$, clearly higher than all mineral values in the granite. Sediment sample B1 is largely depleted (-60\%) with a 
$268 \delta^{7} \mathrm{Li}$ value close to $0 \%$. Soil sample B2 is depleted around $-50 \%$ with a more negative $\delta^{7} \mathrm{Li}$

269 value of $-2.7 \%$. Compared to the significant variation in $\delta^{7} \mathrm{Li}$ values, the $\mathrm{Li}$ concentration 270 remains largely constant in the three samples with a total variation of around 8\% (Fig. 3). Quartz 271 reaches $65 \%$ in surface saprolite sample B0, K-feldspar and illite-smectite having a similar 272 abundance $(\sim 20 \%)$, but plagioclase is only 5\%. Riverbank sediment sample B1 contains around $27325 \%$ quartz, and 20\% K-feldspar, 20\% plagioclase and 20\% illite-mica, but only 5\% chlorite 274 with $15 \%$ as an amorphous phase. Soil sample B2 contains the least quartz (15-20\%), but K275 feldspar, illite-micas and plagioclase contents are still around $20 \%$. Again, the $\delta^{7} \mathrm{Li}$ values 276 become more negative from surface saprolite to soil, which can be explained by changes in 277 mineral abundance in the samples, as higher amounts of residual minerals in the soil sample 278 lead to more negative $\delta^{7} \mathrm{Li}$ values.

\subsection{Atmospheric input correction to surface and groundwater}

The need to quantify and subtract the portion of elements contributed by precipitation in the chemical composition of surface- and ground-waters has been apparent for several decades (e.g., Stallard and Edmond, 1981; Meybeck, 1983). Basically, quantifying the precipitation input requires knowledge of its chemical composition (Négrel et al., 1993; Grobois et al., 2000).

284 The classic reference of atmospheric input in unpolluted hydrosystems is chloride, which 285 behaves conservatively throughout the hydrological cycle; the correction for its atmospheric contribution is estimated by reference to the $\mathrm{Cl}$ concentration in river water, multiplied by the ratio element/Cl of precipitation (e.g., Meybeck, 1983; Négrel et al., 1993). As stated by Négrel 288 (2006), in the absence of evaporites in the Margeride catchment, $\mathrm{Cl}$ ions in the river water can 289 be assumed to originate from wind-blown sea salt and human activity. High $\mathrm{Cl}$ contents can be 290 found in (thermo-mineral) groundwater emerging as naturally flowing springs, which are 291 closely related to fractures in the granite that cannot play any role in supplying $\mathrm{Cl}$ to the river 292 water. This would have been different in the case of an unexposed basement rock with a cover 
of sedimentary rock, as described by Négrel et al. (1997). In our mass-balance approach, determining input-output budgets for dissolved constituents in waters similar to Négrel's (2006) work, we used the mean weighted rainfall on the Massif Central over 1.5 years for $\mathrm{Cl}$ content (Négrel and Roy, 1998).

To determine the highest chloride concentration derived from precipitation input, the standard method (Meybeck, 1983; Négrel et al., 1993) is to multiply the mean weighted $\mathrm{Cl}$ value by a concentration factor $\mathrm{F}$ resulting from evapotranspiration. With a mean weighted chloride of around $20 \mu \mathrm{mol} \mathrm{L}-1$ and an $\mathrm{F}$ value of approximately 1.6 , around $32 \mu \mathrm{mol} \mathrm{L}-1$ represent the highest chloride concentration originating from atmospheric input to the river. When the $\mathrm{Cl}$ content in water is below $32 \mu \mathrm{mol} \mathrm{L}^{-1}$ (Table 1), the entire chloride content of the river is assigned an atmospheric origin; when it is over $32 \mu \mathrm{mol} \mathrm{L}{ }^{-1}$, the residual chloride in the river is attributed to human activity (Meybeck, 1983).

Using rainwater samples obtained during a rain-input survey over the Massif Central (Négrel and Roy, 1998), Millot et al. (2010b) reported low lithium concentrations, between 0.004 and $0.292 \mu \mathrm{mol} \mathrm{L}{ }^{-1}$, whereas the $\delta^{7} \mathrm{Li}$ values varied greatly between $+3.2 \%$ and $+95.6 \%$ over the study period. From this observed range, two groups of rainwater with very different Li characteristics were identified (Fig. 4). The first one, named "natural", had a Li concentration of $0.04 \mu \mathrm{mol} \mathrm{L}{ }^{-1}$ with a $\delta^{7} \mathrm{Li}$ value of around $+6.9 \%$; the second one, named "anthropogenic",

311 had a Li concentration of $0.13 \mu \mathrm{mol} \mathrm{L}^{-1}$ and a much higher $\delta^{7} \mathrm{Li}$ value of around $+79 \%$. For the

312 Li isotopes, considering natural and anthropogenic components, the average value over the

3131.5 year survey was $+26.2 \%$ and the mean concentration-weighted $\mathrm{Li}$ isotopes value was $314+20.3 \%$ (Millot et al., 2010b). For correcting Li contents and Li isotopes of surface water from 315 rainfall data, we used the average Li content, $0.06 \mu$ mole $\mathrm{L}^{-1}$, and the average $\delta^{7} \mathrm{Li},+26.20 \%$, 316 of all rainwater samples collected in the Massif Central over 1.5 years (Négrel and Roy, 1998; 317 Millot et al., 2010b; Fig. 4). 


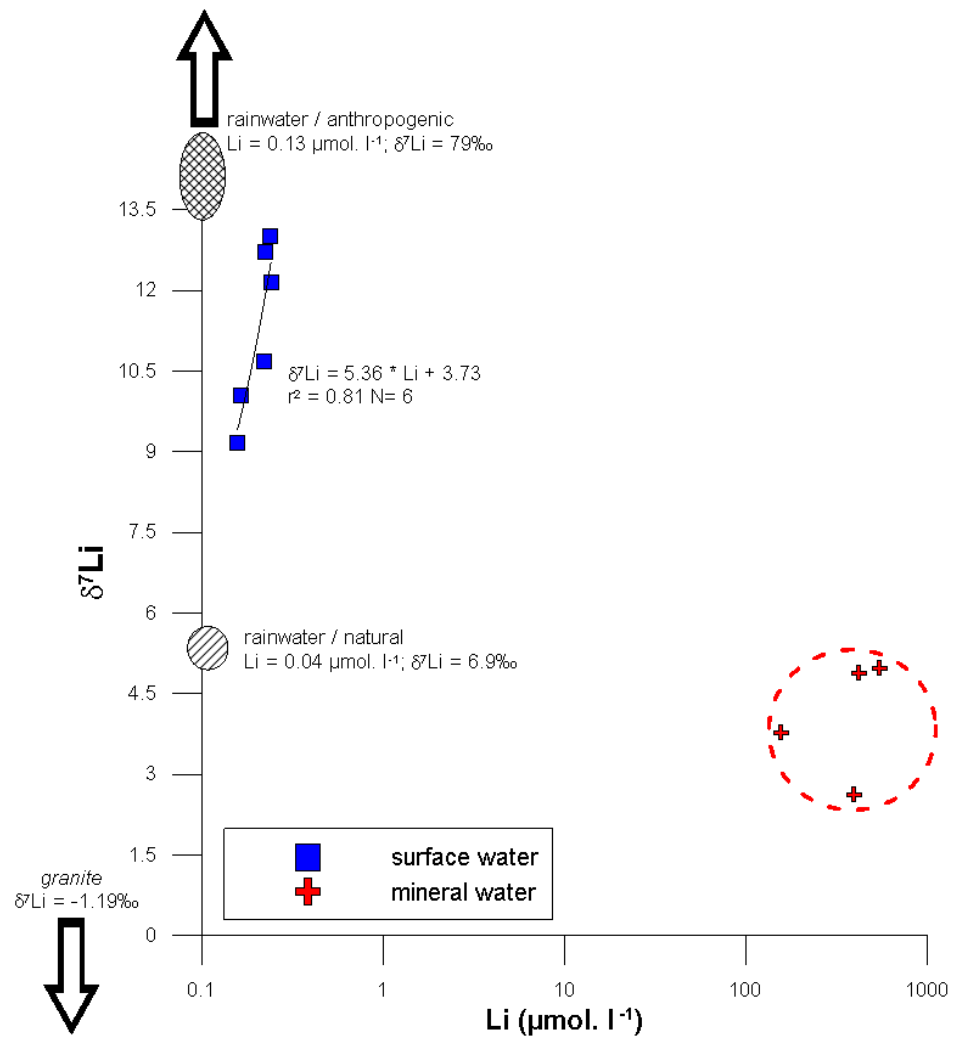

Figure 4. Plot of $\delta^{7} L i$ versus Li concentration $\left(\mu \mathrm{mol} L^{-1}\right)$ for surface water, groundwater and rainwater.

Surface-water samples D8, D9', D9b, D10', D11 and D11' were investigated by Négrel (1999; 2006) for anion contents and now, in this study, for Li (Fig. 4). Applying the atmospheric correction to these surface-water samples showed that D9b and D8 derived their total Cl content from precipitation input and thus reflect no anthropogenic influence, with $35 \%$ and $61 \%$ of the Li deriving from atmospheric input, respectively. This shows a non-negligible influence of precipitation input on the Li budget in this case, contrary to other observations at very different scales by Ryu et al. (2014) in Hawaii, or by Millot et al. (2010) in the Mackenzie Basin of northern Canada.

Other samples have a residual $\mathrm{Cl}$ content that is generally related to anthropogenic input, mainly from agricultural activity. Here, the Li derived from atmospheric input ranged from $40 \%$ in sample D11 to 43\% in samples D9 and D10. Accordingly, as done by Négrel (1999 and 2006)

334 for the same catchment, we corrected the Li-isotope values observed in the water for 
atmospheric contribution, which gave a $\delta^{7} \mathrm{Li}$ ranging from +10.8 (D11') to $-2.0 \%$ (D8). The $\delta^{7} \mathrm{Li}$ for samples without residual $\mathrm{Cl}$ are the lowest, with a $\delta^{7} \mathrm{Li}$ of $-2.0 \%$ for sample $\mathrm{D} 8$ and $+0.8 \%$ o for sample D9b. A similar atmospheric correction to mineralized waters has a low 338 impact on Li content (less than $0.06 \%$ of the Li being from precipitation input) with no change in the $\delta^{7} \mathrm{Li}$ value, indicating the dominant influence of water/rock interaction on both Li content and $\delta^{7} \mathrm{Li}$ value of the mineralized waters.

However, contrary to previous work on atmospheric and anthropogenic corrections to surface-water chemistry (Négrel, 1999; 2006; Petelet-Giraud et al., 2003), we cannot use the same method for anthropogenic-input correction here. The residual $\mathrm{Cl}$ after atmospheric correction derives from anthropogenic input and the correction for such input (e.g. to a zero $\mathrm{Cl}$ content) requires knowledge of its $\mathrm{Li} / \mathrm{Cl}$ ratio. However, this ratio cannot be constrained accurately, which would allow a robust correction for Li content and thus for Li isotopes. Applying the atmospheric correction to the D8, D9, D10 and D11 surface water samples (Négrel, 2006), shows that D8 and D9 derived their total Cl content from atmospheric input, and thus reflect no anthropogenic influence. The Sr content derived from atmospheric input is around $50 \%$ in D9 and $57 \%$ in D8. The influence of atmospheric input on ${ }^{87} \mathrm{Sr} /{ }^{86} \mathrm{Sr}$ ratios is consistently significant (Négrel, 2006), and, corrected for atmospheric input, the ${ }^{87} \mathrm{Sr} /{ }^{86} \mathrm{Sr}$ ratios for water-granite interaction range from 0.72316 (D8) to 0.72511 (D9). Once corrected for atmospheric input, the $\delta^{7} \mathrm{Li}$ value and $\mathrm{Cl}$ concentration are controlled by water-granite 354 interaction and anthropogenic input(s). This is summarized in Fig. 5, where $\delta^{7} \mathrm{Li}$ is plotted versus residual $\mathrm{Cl}$. The two samples with no residual $\mathrm{Cl}$ directly yield the value of the $\delta^{7} \mathrm{Li}$ 356 derived from water-rock interaction, with $\delta^{7} \mathrm{Li}$ values of $+0.8 \%$ (D9) and $-2.0 \%$ (D8) 357 associated with $\mathrm{Li}$ concentrations of 0.11 and $0.06 \mu \mathrm{mol} \mathrm{L}^{-1}$, respectively. The other samples 358 have residual $\mathrm{Cl}$ values from 7.4 (D10) to $49.7 \mu \mathrm{mol} \mathrm{L}^{-1}$ (D11), $\delta^{7} \mathrm{Li}$ value from +6.4\%o (D9) 359 to $+10.8 \%$ (D11) and nearly constant Li concentrations of 0.13 to $0.15 \mu \mathrm{mol} \mathrm{L}^{-1}$. This can be 
related to an increase of the anthropogenic input, with a roughly constant $\delta^{7} \mathrm{Li}$.

362 in fertilizers, such as carbonaceous amendment or NPK, between $+2.1 \%$ ond $+215 \%$ and a mean weighted $\delta^{7} \mathrm{Li}$ value of $+14.2 \%$. For $\mathrm{Li}$ used with other trace elements, such as $\mathrm{Cu}, \mathrm{Fe}$,

364 Mn, Zn, Co, Mo and B, even though not necessary as an additional nutrient (Négrel et al., 2010a), the $\delta^{7} \mathrm{Li}$ ranged between $-16 \%$ and $+31 \%$ o with a mean weighted $\delta^{7} \mathrm{Li}$ value of $+1.3 \%$. These two mean values agree with the range observed in surface waters and thus can explain an anthropogenic input from agricultural activities.

368

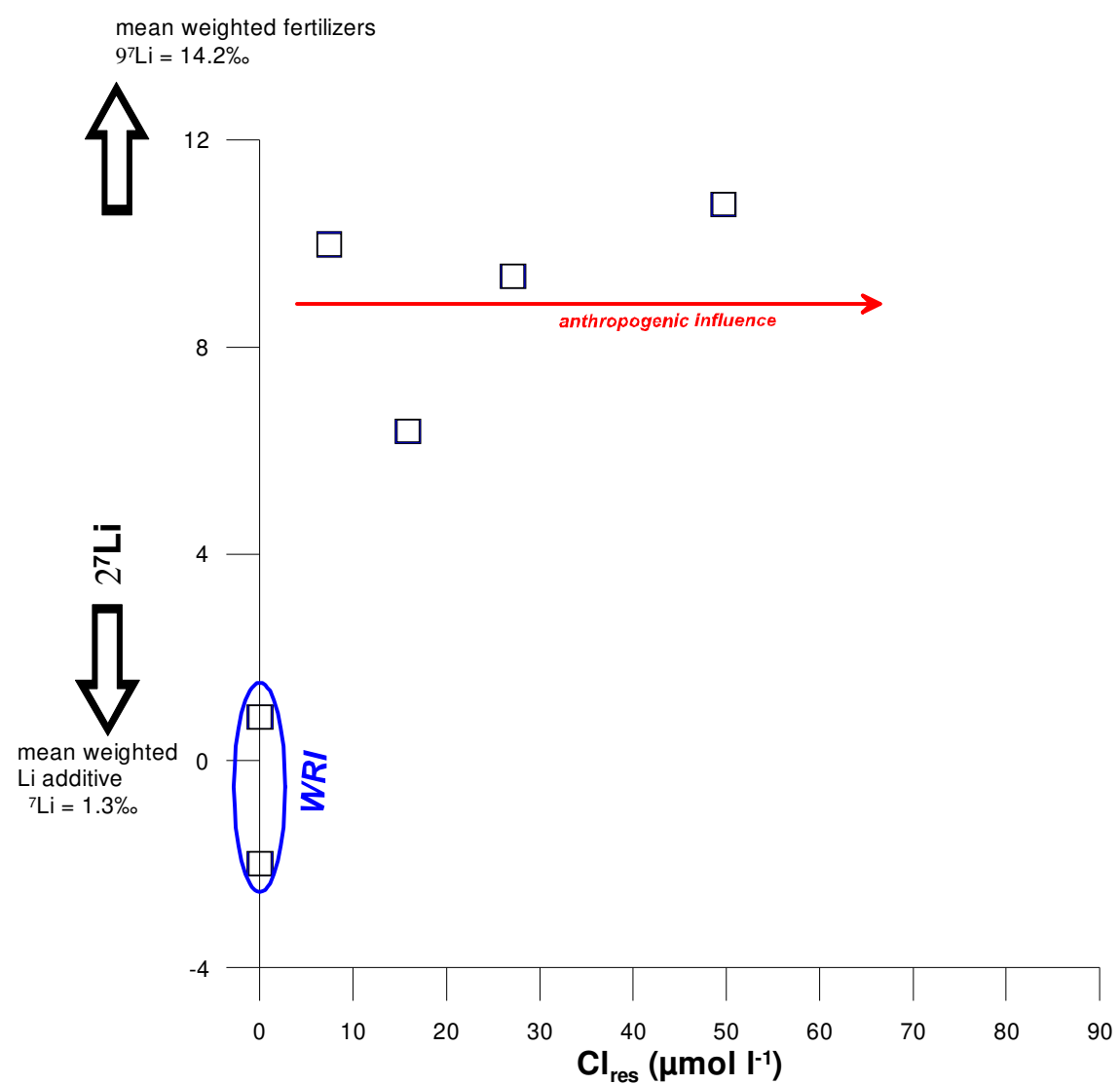

Figure 5. Plot of $\delta^{7} L i$ versus the residual Cl concentration ( $\mu$ mol $\left.L^{-1}\right)$ for surface water, once corrected from precipitation input (see text). The mean weighted $\delta$ Li values for the fertilizers and Li additives used in agricultural practices are indicated. 


\subsection{The weathering model for $\mathrm{Li}$}

\subsubsection{The simple dissolution model}

Négrel et al. (2001) developed a weathering model based on dissolution, giving the theoretical (th) isotopic signature (i) of a chemical element (Z) in water being in equilibrium with granite (iZ $Z_{\text {th }}$, which was initially developed for and applied to strontium. This model considers the congruent dissolution of Sr-bearing phases $(\mathrm{mx})$, their abundance $\left(\%_{\mathrm{mx}}\right)$, isotope ratio $\left(\mathrm{i} \mathrm{Z}_{\mathrm{mx}}\right)$ and element concentration $\left(\mathrm{Z}_{\mathrm{mx}}\right)$. Each mineral characteristic considered (i $\mathrm{Z}_{\mathrm{mx}}$ and $\left.\mathrm{Z}_{\mathrm{mx}}\right)$ is weighted by the weatherability $\left(\mathrm{W}_{\mathrm{mx}}\right)$ of each (Négrel et al., 2001), summarized in equation 2:

$$
i Z_{t h}=\frac{\sum\left(i Z_{m x} \times Z_{m x} \times \%_{m x} \times W_{m x}\right)}{\sum\left(Z_{m x} \times \%_{m x} \times W_{m x}\right)} \quad(\text { Equation 2) }
$$

The theoretical isotopic composition $\left(\mathrm{i}_{\mathrm{th}}\right)$ of water in equilibrium with granite was then used for Sr in several environments (Négrel et al., 2001; Petelet-Giraud et al., 2003; Négrel, 2006), before being redefined and applied to $\mathrm{Nd}$ and $\mathrm{Pb}$ in the present watershed (Négrel, 2006; Négrel et al., 2010b). The initial model was based on the hypothesis that the dissolution of plagioclase, K-feldspar and biotite contributes most elemental Sr. The same set of minerals, plus apatite for $\mathrm{Nd}$, and apatite and allanine for $\mathrm{Pb}$, were then considered (Négrel, 2006; Négrel et al., 2010b). For lead-isotope compositions during granite dissolution, we used the concept of Harlavan and Erel (2002) that highlights the role of accessory phases and primary minerals in controlling the isotope composition during water-rock interaction; for the accessory phases, it was suggested that apatite played a major role. Our model thus assumes that only the fluid concentration changes, the isotopic ratio remaining constant, because the secondary minerals are in equilibrium with the parent solution for $\mathrm{Sr}, \mathrm{Nd}$ and $\mathrm{Pb}$. The relative mineral weatherability $\mathrm{W}_{\mathrm{mx}}$, considering that of plagioclase as 1 , is 0.25 for biotite and 0.1 for $\mathrm{K}$ feldspar (Négrel et al., 2001). A sensitivity analysis of the model (Petelet-Giraud et al., 2003b; Négrel, 2006), based on testing various mineral-weatherability values from the literature (Blum 
et al., 1994; Zuddas et al., 1995), consistently showed only minor differences in the isotope

400 values. The model was verified for $\mathrm{Sr}$ by comparing the $\mathrm{iSr}_{\mathrm{th}}$ calculation for given conditions 401 of $\mathrm{Sr}$ abundance and the isotopic characteristics of separate minerals, with the ${ }^{87} \mathrm{Sr} /{ }^{86} \mathrm{Sr}$ ratio of

402

403

404

405

406

407

408

409

410

411

412

413

water that has interacted with several granitoids and basalts in France (Petelet-Giraud et al., 2003; Négrel, 2006).

For this study, the model was adapted for lithium and applied to the Margeride granite, using data from Table 1. In view of the composition of this granite, we considered K-feldspar, plagioclase and biotite as primary minerals, and apatite as an accessory phase in the model of eq. 2. This was also based on interaction experiments by Millot and Négrel (2013) between a rainwater reference solution (TMRAIN-95) and $1.5 \mathrm{~g}$ of powdered granite sample from India at $25{ }^{\circ} \mathrm{C}$ (Négrel et al., 2010b). Millot and Négrel (2013) monitored Pb- and Li-isotopic compositions over 12 months of interaction, showing that:

i) When using $\mathrm{Pb}$ isotopes, there is a major contribution of $\mathrm{K}$-feldspar and plagioclase dissolution, and, to a lesser extent, of biotite and apatite dissolution;

ii) When using $\mathrm{Li}$ isotopes, the light lithium isotope $\left({ }^{6} \mathrm{Li}\right)$ is preferentially retained during uptake of Li into secondary minerals during weathering.

The theoretical $\delta^{7} \mathrm{Li}$ signature for water draining this granite is close to $-3.3 \%$. The difference in the isotopic values is always less than 0.1 for Li during sensitivity analysis of the model, done by testing various mineral-weatherability values similar to the $\mathrm{Sr}, \mathrm{Nd}$ and $\mathrm{Pb}$ models (Petelet-Giraud et al., 2003; Négrel, 2006; Négrel et al., 2010b). Our model only provides information on the isotopic value of water after interaction with minerals; it does not assume that the main process associated with isotope fractionation is the formation of secondary precipitates, such as clays, even though the evolution of Li-isotope values is controlled by the precipitation of secondary minerals, as was shown in other environments (Huh et al., 2001; Pistiner and Henderson, 2003; Vigier et al., 2008; Millot et al., 2010). 


\subsubsection{A broader weathering frame using $\mathrm{Li}$ and $\mathrm{Sr}$ isotopes: Implications for water/rock}

\section{interaction in the critical zone}

427 Figure 6 is a plot of the $\delta^{7} \mathrm{Li} v s .{ }^{87} \mathrm{Sr} /{ }^{86} \mathrm{Sr}$ values, where the results from primary minerals and accessory phases of the granites, the whole rock, the soil and sediment samples, and the mineralwater and surface-water samples, are plotted with the results of the weathering-model computation for the granite. The Sr-isotope systematics for primary minerals and accessory phases of the granites, whole rock, soil and sediment samples, and mineral-water data are from Négrel (2006), and those for surface-water samples are from Négrel (1999).

Figure 6 shows several features: 1) For surface waters, the $\delta^{7} \mathrm{Li}$ and ${ }^{87} \mathrm{Sr} /{ }^{86} \mathrm{Sr}$ values disagree with the weathering model, even if $\mathrm{Li}$ is not corrected for atmospheric input, the $\delta^{7} \mathrm{Li}$ being either lower or higher than the model value. 2) For thermo-mineral spring waters, there is again no agreement with the results of the weathering model, all springs having a higher $\delta^{7} \mathrm{Li}$ than the weathering model, and a larger influence caused by an increase in weathering of one or more minerals cannot explain the values observed for $\delta^{7} \mathrm{Li}$ values in the mineralized waters, no minerals in the Margeride granite having such a high $\delta^{7} \mathrm{Li}$ value. This is particularly true for the residual trace minerals that cannot control the $\delta^{7} \mathrm{Li}$ values of the water (Figs. 3 and 6). For thermo-mineral spring waters, the $\delta^{7} \mathrm{Li}$ values thus suggest that other processes lead to the observed signatures because the ${ }^{87} \mathrm{Sr} /{ }^{86} \mathrm{Sr}$ ratio agrees with the results of the weathering model. 3) For the residual solids, the ${ }^{87} \mathrm{Sr} /{ }^{86} \mathrm{Sr}$ difference between whole rock (0.72269) and Mazel grit (0.73134) reflects the weathering of low ${ }^{87} \mathrm{Sr} /{ }^{86} \mathrm{Sr}-$ and $\mathrm{Rb} / \mathrm{Sr}$-bearing minerals, such as plagioclase and K-feldspar; this is confirmed by the grit mineralogy ( $20 \%$ of each in this sample; Négrel, 2006), whereas the Mazel grit shows a depleted $\delta^{7} \mathrm{Li}$ compared to the whole rock. 4) Riverbank sediment A1 at site D19 shows an ${ }^{87} \mathrm{Sr} /{ }^{86} \mathrm{Sr}$ ratio of 0.74408 and a $\delta^{7} \mathrm{Li}$ of $0.1 \%$, both higher than that of the grit. An increase in the Sr-isotope ratio is noted in the 
sediment from surface saprolite A0 $\left({ }^{87} \mathrm{Sr} /{ }^{86} \mathrm{Sr}=0.75085\right)$ down to soil A2 $\left({ }^{87} \mathrm{Sr} /{ }^{86} \mathrm{Sr}=0.75290\right)$, accompanied by a large decrease in $\delta^{7} \mathrm{Li}$ (from +0.1 to $-3.4 \%$ ). In site $\mathrm{D} 17$, soil $\mathrm{B} 2$ has the lowest ${ }^{87} \mathrm{Sr} /{ }^{86} \mathrm{Sr}$ ratio $(0.76296)$ and $\delta^{7} \mathrm{Li}\left(-2.7 \%\right.$ ) , and, as for site D19, the ${ }^{87} \mathrm{Sr} /{ }^{86} \mathrm{Sr}(0.76649)$ in sediment B1 collected on the river bank increases to 0.78508 in surface saprolite B0, accompanied by a large increase in the $\delta^{7} \mathrm{Li}$ (from 0 to $+3.3 \%$ ).

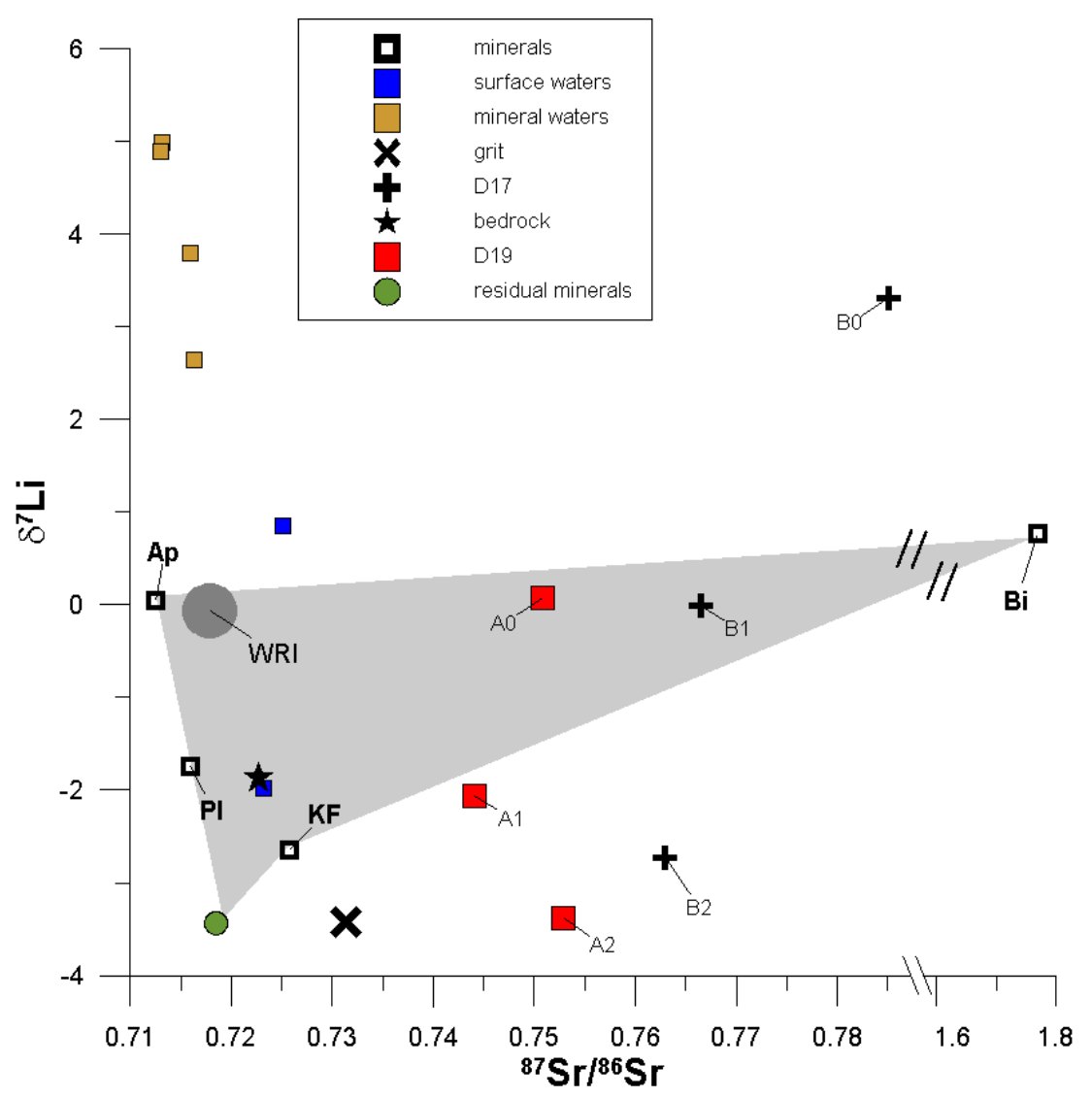

454

Figure 6. Relationship between the $8 \mathrm{Li}$ and ${ }^{87} \mathrm{Sr} /{ }^{86} \mathrm{Sr}$ for Margeride granite, separate minerals and Mazel grit sample, and surface and mineralized spring waters. $8 \mathrm{Li}$ and ${ }^{87} \mathrm{Sr}{ }^{86} \mathrm{Sr}$ of the remaining trace minerals (titanite, rutile, epidote, zircon) are indicated in the graph (see text). The result of the weathering model is indicated by the grey circle (see text). The separate minerals from the granite define the greyed area with the addition of residual minerals.

\subsubsection{Modelling Li isotopic fractionation using a Raleigh equation: the role of secondary} phase precipitation

Here, we apply the batch fractionation model for Li isotopes as developed by Bouchez et al. (2013) and used by Clergue et al. (2015). This model is based on the non-congruent dissolution of bedrock leading to a $\delta^{7} \mathrm{Li}$ in solution $\left(\delta^{7} \mathrm{Li}_{\text {solution }}\right)$. As a first approach, this model is only 
based on (non congruent) dissolution/precipitation reactions. The main process occurring in this 467 solution is Li-isotope fractionation through the formation of secondary phases that 468 preferentially incorporate light lithium $\left({ }^{6} \mathrm{Li}\right)$. This gives a residual solution with a $\delta^{7} \mathrm{Li}_{\text {diss }}$ and a $469 \quad \delta^{7} \mathrm{Li}_{\text {sec }}$ for the secondary phases. The $\delta^{7} \mathrm{Li}_{\text {sec }}$ can be expressed as follows:

470

$$
\delta^{7} \mathrm{Li}_{\text {sec }}=\frac{\alpha \times \delta^{7} \mathrm{Li}_{\text {rock }}+1000 \mathrm{f}_{\mathrm{Li}}(\alpha-1)}{\alpha\left(1-\mathrm{f}_{\mathrm{Li}}\right)+\mathrm{f}_{\mathrm{Li}}}
$$

(Equation 3)

The key parameters are the isotope fractionation factor $\delta^{7} \mathrm{Li}_{\text {sec }}$ between the different secondary minerals, and the solution $\left(\delta^{7} \mathrm{Li}_{\text {solution }}\right)$ and proportion $\left(1-\mathrm{f}_{\mathrm{Li}}\right)$ of $\mathrm{Li}$ in secondary phases. The $f_{\text {Li }}$ can be expressed by the elemental mass transfer coefficient $\tau$ calculated with equation (1), which represents the evolution of the $\mathrm{Li} / \mathrm{Ti}$ ratio in sediment compared to that of bedrock.

The isotope fractionation factor is calculated from chemical and isotope data measured on field material; this can be applied to samples from soil, rivers and the sedimentary record, and does not require prior knowledge of the isotope fractionation factors involved in the detailed reactions. Weathering products are modelled here with a fractionation factor $\alpha_{\text {sec-dis }}$ ranging from 0.975 to 0.998 , consistent with the range of $\alpha$ values used in the literature (Rudnick et al., 2004; Clergue et al., 2015). To summarize, the $\alpha$ values in the literature span a range from 0.970 to 1.000 and derive either from laboratory experiments (0.979-0.984, Millot et al., 2010c; Vigier et al., 2008), or from field data (0.982-0.989, Millot et al., 2010a, 2010c; Tipper et al., 2012; Dellinger et al., 2013; 2014; 2015).

We found that the fractionation factor $\alpha_{\text {sec-dis }}$ on Figure 7 can explain some, but not all, weathering products; the lowest $\delta^{7} \mathrm{Li}$ observed in the samples fit with the $\alpha$ max (0.998), but no point is explained by the $\alpha \min (0.975)$. Thus, we cannot fit the required fractionation factor 
$\alpha_{\text {sec-dis }}$ to the soil and sediment data (Fig. 7). Additional processes or inputs should thus be considered and investigated. than the one defined from experimental clay precipitation, Lemarchand et al. (2010) argued for the precipitation of another possible phase with a higher isotope fractionation. As far as we know, no studies have been carried out on such phases, but oxides could be a good candidate for the fractionation of $\mathrm{Li}$ isotopes and can account for the existence of high $\delta^{7} \mathrm{Li}$ values in weathering products. This argument was already proposed by Millot et al. (2010a) to explain incipient weathering effects on Li isotopes in the Canadian Rocky Mountains. Concerning our samples, only B1 and B2 have an amorphous phase identified by X-ray diffraction (15 and 5\%, respectively; Négrel, 2006), agreeing with a $\delta^{7} \mathrm{Li}$ shift away from the $\alpha$ max line, but only for 499 B1, as sample B2 plots close to the $\alpha$ max line. Conversely, no amorphous phase was identified 500 in samples $\mathrm{A} 0$, $\mathrm{A} 1$ and $\mathrm{B} 0$, though the $\delta^{7} \mathrm{Li}$ is shifted from the $\alpha$ max line. Thus, the 501 precipitation of secondary clay minerals is not enough to explain the $\delta^{7} \mathrm{Li}$ shift and the role of 502 other phase-like oxides must be considered.

$\mathrm{Fe}-\mathrm{Mn}$ oxides, one of the main oxides in the non-residue part of soils and river sediments, have an exceptional tendency (particularly Mn oxides) for scavenging trace 505 elements $(\mathrm{Cu}, \mathrm{Zn}, \mathrm{Ni}, \mathrm{Pb}$, etc.; Carpenter et al., 1975), Li not being investigated to our 506 knowledge. One of the few studies describing Li-isotope values in Fe-Mn oxides is that of You 507 and Chan (1996), giving $\delta^{7} \mathrm{Li}$ values between +22.9 and $+33.4 \%$ for hydrothermal 508 ferromanganese crusts, such values being controlled by post-depositional exchange with 509 seawater. To overcome this lack, we can use data from the labile fraction extracted from soils 510 and river sediments in the same catchment (Négrel and Roy, 2002; Négrel and Petelet-Giraud, 511 2012). These were obtained by leaching with cold and dilute acid, which releases the total 512 inventory of non-residual trace elements, particularly those associated with hydrous $\mathrm{Fe}-\mathrm{Mn}$ 
oxides adsorbed on clays, and occurring in carbonates and sulphides in the sediment load, as

514 well as in natural organic matter. The content of the labile sample fractions from this study is consistently low, with similar ranges in soil and sediment $(0.8-10.1 \%$ of total matter content;

516 mean $6.4 \%$ ). The Mn contents of this labile fraction range between 50 and $30,000 \mu \mathrm{g} / \mathrm{g}$ (mean $517 \pm 6,000 \mu \mathrm{g} / \mathrm{g})$. In addition, strong $\mathrm{Li}-\mathrm{Fe}$ and $\mathrm{Li}-\mathrm{Mn}$ correlations exist in agricultural soil at a 518 European scale (GEMAS Project; Négrel et al., 2018). This is strongly related to precipitation of 519 Fe-Mn oxide/hydroxide coatings, which provides a control over the lithium content within such 520 phases that encourages investigating the labile fractions in soil and sediment for Li isotopes to evaluate Li isotope fractionation during the formation of Fe-Mn oxides.

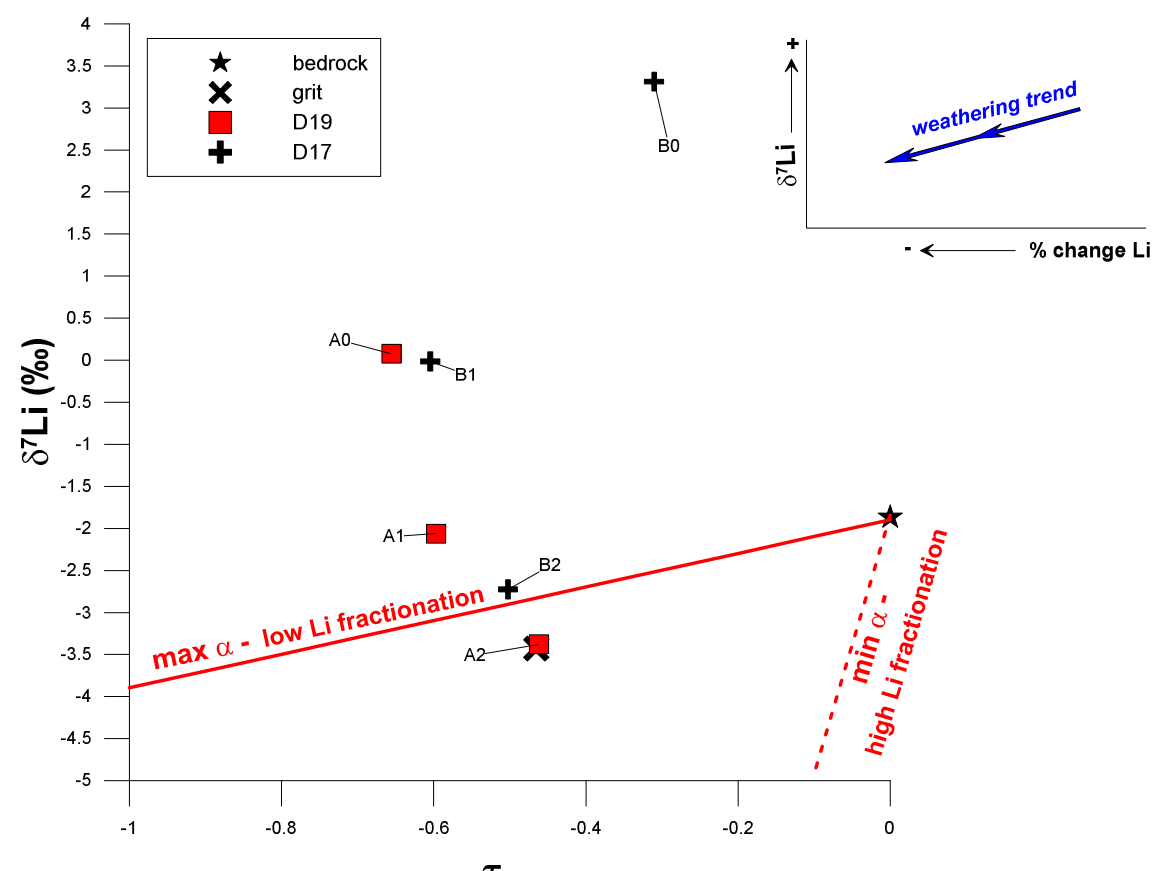

523 Figure 7. Li isotopic composition of surface saprolite (AO, B0), riverbank sediments (A1, B1) and soil samples $(A 2, B 2)$ as a function of $\tau L i$ (Equation 1). Straight lines represent the evolution of $\delta^{7} L i$ vs. $\tau L i$ given by the batch equilibrium model according to Equation 3.

The Margeride data can be compared with other granite areas, but studies on granite and associated weathering products are relatively rare (Rudnick et al., 2004; Lemarchand et al., 2010), only the latter concerning the same type of granite as the Margeride. It presents analyses

530 of Li concentrations and isotopic compositions in rock, soil, vegetation, soil water, rainfall,

531 springs and stream water of the Strengbach catchment. This forested catchment in the Vosges 
532 Mountains (NE France) has been intensively studied and monitored for decades by the

533 University of Strasbourg. The bedrock is a leucogranite affected by hydrothermal alteration,

534 the weathering products being saprolite $(\leq 10 \mathrm{~m}$ thick) and soil overlying the saprolite $( \pm 80 \mathrm{~cm}$

535 thick). Fractionation factors $\alpha_{\text {sec-dis }}$ are illustrated on Figure 8 for the Strengbach catchment with

536 the Margeride data (Fig. 7).

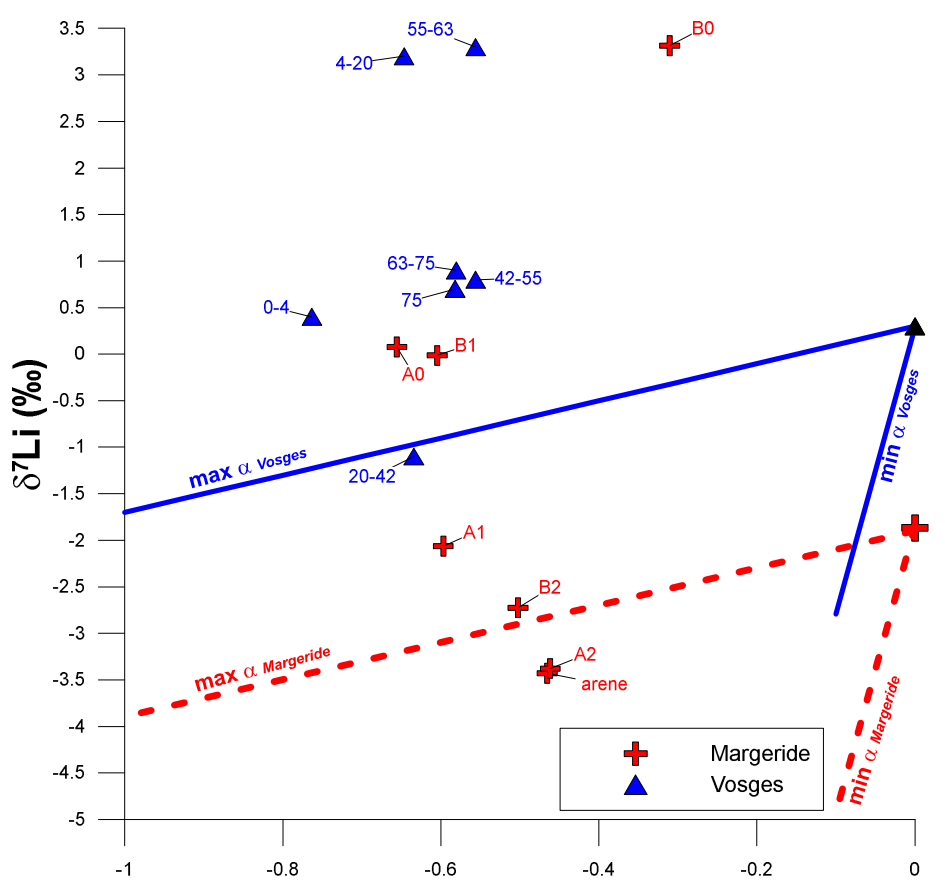

537

538

539

540

541

542

543

544

545

$\tau_{\text {Li }}$

Figure 8. Comparison of Li isotopic composition of soil samples as a function of $\tau$ Li for the Margeride catchment (this study, Fig. 7) and the Strengbach granitic catchment (Vosges Mountains, France; Lemarchand et al., 2010). For the latter, the numbering indicates the depth interval considered in the profile.

Again, the fractionation factor does not explain most Strengbach data. Only one weathering product can be explained considering the $\alpha \max$ of 0.998 (low Li-isotopic fractionation) and no points are explained by the $\alpha$ min of 0.975 (high fractionation). Lemarchand et al. (2010) argued that soil is a strongly reactive compartment for Li isotopes, and that another phase inducing Li-isotope fractionation must be suspected. Identifying the origin of this fractionation will require more studies at catchment scale for understanding the processes at the biosphere interface. Anderson et al. (1988) demonstrated that exchangeable Li 
551 is an insignificant part of the total Li present in soil, and Reimann et al. (2014a; b) showed a

552 weak affinity of Li for phases like clay and organic matter using Mobile Metal Ion (MMI®)

553 extraction. Combining sequential extraction with Li isotope measurements can help explore

554 how $\mathrm{Li}$ is bounded to the different mineral phases and identify the phases that cause the

555 fractionation in soil and sediment.

\section{6-Conclusions}

557 We carried out a systematic study of lithium-isotope compositions of surface- and groundwaters, and soil and sediment samples collected from a granite catchment in the French Massif Central. This work incorporates many novel aspects, being an integrated investigation of weathering processes by means of lithium isotopes.

In water, the lithium isotope composition $\left(\delta^{7} \mathrm{Li}\right)$ of a dissolved load is generally higher than corresponding $\delta^{7} \mathrm{Li}$ values for groundwater, bedrock and sediment. It has been suggested that Li-isotope fractionation in the dissolved load records silicate weathering intensity, as well as fluid-residence time, or exchange processes between water and sediment. In soil and sediment, $\mathrm{Li}$ is enriched through fractionation into the lithium- 6 and -7 isotopes, leading to less negative $\delta^{7} \mathrm{Li}$ values and to changes in mineral abundance in the samples.

A model for determining the $\delta^{7} \mathrm{Li}$ of water after interaction with granite was applied, based on the assumption that $\mathrm{Li}$ derives from plagioclase, $\mathrm{K}$-feldspar, apatite and biotite. The model calculations showed a relative agreement between the Li isotope composition predicted by the weathering model and that observed in water.

The fractionation process during granite weathering was investigated through non-

572 congruent dissolution of the bedrock, leading to a $\delta^{7} \mathrm{Li}$ in solution. The main process caused by 573 this solution is the fractionation of $\mathrm{Li}$ isotopes through the formation of secondary phases that 574 preferentially incorporate light lithium $\left({ }^{6} \mathrm{Li}\right)$. This gives a residual solution with a specific $\delta^{7} \mathrm{Li}$ 575 and another $\delta^{7} \mathrm{Li}$ value for the secondary phases. 
We modelled weathering products with a fractionation factor that is consistent with the range of values found in the literature. Our results show that some, but not all, weathering products can be explained by such fractionation. Additional processes or inputs must therefore be investigated, such as the precipitation of another phase with a higher isotope fractionation rate, for which Fe-Mn oxides are a good candidate. Data from the Margeride were compared with those from the Strengbach granite catchment in the Vosges Mountains (NE France); again, the fractionation factor did not explain most Strengbach data and, here too, the role of another phase was suspected.

We highlighted the possible role of $\mathrm{Li}$ isotopes as tracers of water-rock interaction in a granite catchment. When evaluating regolith (soil and sediment) formation, any additional tracers to the basic ones (major- and trace elements, and $\mathrm{Sr}$ isotopes) are important for constraining the whole weathering system.

A remaining problem to be solved concerns the distinction between primary effects related to source/origin, and the effects of secondary processes (alteration, dissolution, precipitation) that can modify the isotopic signature, and are key reactions for fractionating $\mathrm{Li}$

591 isotopes. Another approach to understanding and interpreting the isotopic signatures will 592 require Reactive Transport Model (RTM) computer simulations, to arrive at simultaneous solution of the governing equations for solute and geochemical transformations.

\section{Acknowledgements}

596 This work was financially supported by the BRGM Research Division 'Isotopes' research programmes,

597 and benefited from collaboration by the BRGM Chemistry laboratories for major- and trace element

598 analyses: T. Conte is thanked for his assistance, as well as M. Robert for her help in the Neptune 599 laboratory. Financial support from the Région Centre is acknowledged for acquisition of the Neptune 600 MC-ICP-MS. We are grateful to Dr. H.M. Kluijver for proofreading and editing the English text. Paul 601 Tomascak, two anonymous reviewers and Editor-in-Chief Karen Johannesson are warmly thanked for 
their critical comments and constructive reviews that greatly improved the manuscript, and for proofreading and editing the English text. This paper is dedicated to the memory of our wonderful colleague and friend, Dr. Tom Bullen, who recently passed away (Shouakar-Stash et al., 2018).

\section{References}

Abbas, N., Subramanian, V. 1984. Erosion and sediment transport in the Ganges river basin (India). J. Hydrol., 69 173-182.

Ackerer, J., Chabaux, F., van der Woerd, J., Viville, D., Pelt, E., Kali, E., Lerouge, C., Ackerer, P., di Chiara Roupert, R, Négrel, Ph. 2016. Regolith evolution on the millennial timescale from combined $\mathrm{U}-\mathrm{Th}-\mathrm{Ra}$ isotopes and in situ cosmogenic ${ }^{10} \mathrm{Be}$ analysis in a weathering profile (Strengbach catchment, France). Earth Planet. Sci. Lett., 453, 33-43.

Amiotte Suchet, P., Probst, J.L., Ludwig, W. 2003. Worldwide distribution of continental rock lithology: Implications for the atmospheric/soil $\mathrm{CO}_{2}$ uptake by continental weathering and alkalinity river transport to the oceans. Global Biogeochemical Cycles, 17(2).

Anderson, M.A., Bertsch, P.M., Miller, W.P. 1988. The distribution of lithium in selected soils and surface waters of the southeastern USA. App. Geochem., 3, 205-212.

Begonha, A., Sequeira Braga, M.A., 2002. Weathering of the Oporto granite: geotechnical and physical properties. Catena, 49, 57-76.

Bouchez J., von Blanckenburg F., Schuessler J.A. 2013. Modeling novel stable isotope values in the weathering zone. Am. J. Sci., 313, 267-308.

Braga, M.S., Paquet, H., Begonha, A. 2002. Weathering of granites in a temperate climate (NW Portugal): granitic saprolites and arenization. Catena, 49, 41-56.

Brimhall, G.H., Dietrich, W.E. 1987. Constitutive mass balance relations between chemical composition, volume, density, porosity, and strain in metasomatic hydrochemical systems: results on weathering and pedogenesis. Geochim. Cosmochim. Acta, 51, 567-587.

Carpenter R.H., Pope T.A., Smith R.L. 1975. Fe-Mn oxide coatings in stream sediment geochemical surveys. J. Geochem. Expl., 4, 349-363.

Clergue, C., Dellinger, M., Buss, H.L., Gaillardet, J. Benedetti, M.F., Dessert C. 2015. Influence of atmospheric deposits and secondary minerals on $\mathrm{Li}$ isotopes budget in a highly weathered catchment, Guadeloupe (Lesser Antilles). Chem. Geol., 414, 28-41.

Dellinger, M., Gaillardet, J., Bouchez, J., Calmels, D., Louvat, P., Gorge, C., Maurice, L., 2013. Lithium isotopic composition of the dissolved load in the Amazon River Basin. Mineral. Mag., 77, 967.

Dellinger, M., Gaillardet, J., Bouchez, J., Calmels, D., Galy, V., Hilton, R. G., Louvat, P. France-Lanord, C. 2014. Lithium isotopes in large rivers reveal the cannibalistic nature of modern continental weathering and erosion. Earth Planet. Sci. Lett., 401, 359-372. 
Dellinger, M., Gaillardet, J., Bouchez, J., Calmels, D., Louvat, P., Dosseto, A., Gorge, C., Alanoca, L., Maurice, L. 2015. Riverine Li isotope fractionation in the Amazon River basin controlled by the weathering regimes. Geochim. Cosmochim. Acta, 164, 71-93.

Gaillardet, J., Dupré, B., Louvat, P., Allègre, C.J. 1999. Global silicate weathering and $\mathrm{CO}_{2}$ consumption rates deduced from the chemistry of the large rivers, Chem. Geol., 159, 3-30.

Grosbois, C., Négrel, Ph., Fouillac, C., Grimaud, D. 2000. Dissolved load of the Loire River: chemical and isotopic characterization. Chem. Geol., 170, 179-201.

Harlavan, Y., Erel, Y., 2002. The release of Pb and REE from granitoids by the dissolution of accessory phases. Geochim. Cosmochim. Acta, 66, 837-848.

Hathorne, E.C., James, R. H. 2006. Temporal record of lithium in seawater: A tracer for silicate weathering?. Earth Planet. Sci. Lett., 246, 393-406.

Henchiri, S., Gaillardet, J., Dellinger, M., Bouchez, J., Spencer, R.G.M. 2016. Riverine dissolved lithium isotopic signatures in low-relief central Africa and their link to weathering regimes. Geophys. Res. Lett., 43, doi:10.1002/2016GL067711.

Henchiri S., Clergue C., Dellinger M., Gaillardet J., Louvat P. Bouchez J. 2014. The influence of hydrothermal activity on the Li isotopic signature of rivers draining volcanic areas. Proc. Earth Planet. Sci., 10, 223-230.

Huh, Y., Chan, L.H., Zhang, L., Edmond, J.M. 1998. Lithium and its isotopes in major world rivers: Implications for weathering and the oceanic budget. Geochim. Cosmochim. Acta, 62, 2039-2051.

Huh, Y., Chan, L.H., Edmond, J.M. 2001. Lithium isotopes as a probe of weathering processes: Orinoco River. Earth Planet. Sci. Lett., 194, 189-199.

Huh, Y, Chan, L.H., Zhang, L., Edmond, J.M. 1998. Lithium and its isotopes in major world rivers: Implications for weathering and the oceanic budget. Geochim. Cosmochim. Acta, 62, 2039-2051.

Huh, Y., Chan, L.H., Chadwick, O.A. 2004. Behavior of lithium and its isotopes during weathering of Hawaiian basalt. Geochem. Geoph. Geosyst., 5(9), 1-22.

Kisakurek, B., Widdowson, M., James, R.H. 2004. Behaviour of Li isotopes during continental weathering: the Bidar laterite profile, India. Chem. Geol., 212, 27-44.

Kisakurek, B., James, R.H., Harris, N.B.W. 2005. Li and $\delta^{7} \mathrm{Li}$ in Himalayan rivers: Proxies for silicate weathering? Earth Planet. Sci. Lett., 237, 387- 401

Le Pera, E., Critelli, S., Sorriso-Valvo, M. 2001. Weathering of gneiss in Calabria, southern Italy. Catena, 42, 1-15.

Liu, C.Q., Zhao, Z.Q., Wang, Q., Gao, B. 2011. Isotope compositions of dissolved lithium in the rivers Jinshajiang, Lancangjiang, and Nujiang: Implications for weathering in Qinghai-Tibet Plateau. App. Geochem., 26, S357-S359.

Liu, X.M. Wanner, C., Rudnick, R.L., McDonough, W.F. 2015. Processes controlling $\delta^{7} \mathrm{Li}$ in rivers illuminated by study of streams and groundwaters draining basalts. Earth Planet. Sci. Lett., 409, 212224. 
Lemarchand, E. Chabaux, F., Vigier, N., Millot, R. Pierret, M.C. 2010. Lithium isotope systematics in a forested granitic catchment (Strengbach, Vosges Mountains, France). Geochim. Cosmochim. Acta, $74,4612-4628$.

Meybeck, M., 1983. Atmospheric inputs and river transport of dissolved substances. IAHS Publ., 141, 173-192.

Millot, R., Guerrot, C., Vigier, N. 2004. Accurate and high precision measurement of lithium isotopes in two reference materials by MC-ICP-MS. Geostandards and Geoanalytical Res., 28, 153-159.

Millot, R., Vigier, N., Gaillardet, J. 2010a. Behaviour of lithium and its isotopes during weathering in the Mackenzie Basin, Canada. Geochim. Cosmochim. Acta, 74, 3897-3912.

Millot, R., Petelet-Giraud, E., Guerrot, C., Négrel, Ph. 2010b. Multi-isotopic composition $\left(\delta^{7} \mathrm{Li}-\delta^{11} \mathrm{~B}-\right.$ $\delta \mathrm{D}-\delta^{18} \mathrm{O}$ ) of rainwaters in France: Origin and spatio-temporal characterization. Appl. Geochem., 25, $1510-1524$.

Millot, R., Scaillet, B., Sanjuan, B. 2010c. Lithium isotopes in island arc geothermal systems: Guadeloupe, Martinique (French West Indies) and experimental approach. Geochim. Cosmochim. Acta, 74, 1852-1871.

Millot, R., Négrel, Ph., Petelet-Giraud, E. 2007. Multi-isotopic (Li, B, Sr, Nd) approach for geothermal reservoir characterization in the Limagne Basin (Massif Central, France). Appl. Geochem., 22, 23072325.

Millot, R., Négrel, Ph. 2007. Multi-isotopic tracing $\left(\delta^{7} \mathrm{Li}, \delta^{11} \mathrm{~B},{ }^{87} \mathrm{Sr} /{ }^{86} \mathrm{Sr}\right)$ and chemical geothermometry: evidence from hydro- geothermal systems in France. Chem. Geol., 244, 664-678.

Millot, R., Négrel, Ph. 2013. Chemical weathering of granitic rocks: experimental approach and Pb-Li isotopes tracing. Proc. Earth Planet. Sci., 7, 590-593.

Millot, R., Tremosa, J., Négrel, Ph. 2019. Chemical weathering of a granitic watershed: coupling Lithium isotopes and reactive transport modeling, preliminary results. WRI-16, Tomsk, Russia, July 21-26 2019.

Murphy, M.J., Porcelli, D., von Strandmann, P.A.E., Hirst, C.A., Kutscher, L., Katchinoff, J.A., Mörth, C.M., Maximov, T., Andersson, P.S. 2019. Tracing silicate weathering processes in the permafrostdominated Lena River watershed using lithium isotopes. Geochim. Cosmochim. Acta, 245, 154-171.

Négrel, Ph., Casanova, J., Aranyossy, J.F. 2001. Strontium isotope systematics used to decipher the origin of groundwaters sampled from granitoids: the Vienne case (France). Chem. Geol., 177, 287308.

Négrel, Ph, Allègre, C.J., Dupré, B., Lewin, E. 1993. Erosion sources determined from inversion of major, trace element ratios and strontium isotopic ratios in river water: the Congo Basin case. Earth Planet Sci. Lett., 120, 59-76.

Négrel, Ph., Guerrot, C., Cocherie, A., Azaroual, M., Brach, M., Fouillac, C. 2000. Rare Earth Elements, neodymium and strontium isotopic systematics in mineral waters: evidence from the Massif Central, France. Appl. Geochem., 15, 1345-1367. 
Negrel, Ph., Fouillac, C., Brach, M. 1997. Occurrence of mineral water springs in the stream channel of the Allier River (Massif Central, France): Chemical and Sr isotope constraints. J. Hydrol., 203, 143153.

Négrel, Ph. 1999. Geochemical study of a granitic area - The Margeride Mountains, France: chemical element behavior and ${ }^{87} \mathrm{Sr} /{ }^{86} \mathrm{Sr}$ constraints. Aq. Geochem., 5, 125-165.

Négrel, Ph. 2006. Water-granite interaction: clues from strontium, neodymium and rare earth elements in saprolite, sediments, soils, surface and mineralized waters. Appl. Geochem., 21, 1432-1454.

Négrel, Ph., Millot, R., Brenot, A., Bertin, C. 2010a. Lithium isotopes as tracers of groundwater circulation in a peat land. Chem. Geol., 276, 119-127.

Négrel, Ph., Millot, R., Roy, S., Guerrot, C., Pauwels, H. 2010b. Lead isotopes in groundwater as an indicator of water-rock interaction (Masheshwaram catchment, Andhra Pradesh, India). Chem. Geol., 274 136-148.

Négrel, Ph., Roy, S., 1998. Rain chemistry in the Massif Central (France). A strontium isotopic and major elements study. App. Geochem. 13, 941-952.

Négrel, Ph., Roy, S. 2002. Investigating the sources of the labile fraction in sediments from silicatedrained rocks using trace elements, and strontium and lead isotopes. Sci. Tot. Env., 298, 163-181.

Négrel, Ph., Pauwels, H., Chabaux, F. 2018. Characterizing multiple water-rock interactions in the critical zone through Sr-isotope tracing of surface and groundwater. Appl. Geochem., 93, 102-112.

Négrel, Ph., Petelet-Giraud, E. 2012. Isotopic evidence of lead sources in Loire River sediment. Appl. Geochem., 27, 2019-2030.

Négrel Ph, Millot R, Guerrot C, Petelet-Giraud E, Brenot A, Malcuit E. 2012. Heterogeneities and interconnections in groundwater: coupled B, Li and stable isotope variations in a large aquifer system (France). Chem. Geol., 296-297, 83-95.

Négrel, Ph., Ladenberger A., Reimann, C., Birke, M., Demetriades, A., Sadeghi, M. 2018. Low-density geochemical mapping at continental scale reveals background for emerging tech-critical elements. Geoph. Res. Abstr., 20, EGU2018-18573, EGU General Assembly Vienna 2018.

Nesbitt, H.W., Markovics, G. 1980. Chemical processes affecting alkalis and alkaline earths during continental weathering. Geochim. Cosmochim. Acta, 44, 1659-1666.

Nesbitt, H.W. 1979. Mobility and fractionation of rare earth elements during weathering of a granodiorite. Nature, 279, 206-210.

Paquet, H., Clauer, N. (Eds.). 2012. Soils and Sediments: Mineralogy and Geochemistry. Springer Science \& Business Media, XYZ p.

746 Pistiner, J.S., Henderson G.M. 2003. Lithium-isotope fractionation during continental weathering processes. Earth Planet. Sci. Lett., 214, 327-339. 
Pogge von Strandmann P.A.E., Burton K., James R., van Calsteren P. Gislason S. 2010. Assessing the role of climate on uranium and lithium isotope behaviour in rivers draining a basaltic terrain. Chem. Geol., 270, 227-239.

Pogge von Strandmann, P.A.E., Opfergelt, S., Lai, Y.J., Sigfusson, B., Gislason, S.R., Burton, K.W. 2012. Lithium, magnesium and silicon isotope behavior accompanying weathering in a basaltic soil and pore water profile in Iceland. Earth Planet. Sci. Lett., 339-340, 11-23.

Pogge von Strandmann, P.A.E., Porcelli, D., James, R.H., van Calsteren, P., Schaefer, B., Cartwright, I., Reynolds, B.C., Burton, K.W. 2014. Chemical weathering processes in the Great Artesian Basin: Evidence from lithium and silicon isotopes. Earth Planet. Sci. Lett., 406, 24-36.

Pogge von Strandmann, P.A.E., Fraser, W.T., Hammond, S.J., Tarbuck, G., Wood, I.G., Oelkers, E.H., Murphy, M.J. (2019). Experimental determination of Li isotope behaviour during basalt weathering. Chem. Geol. https://doi.org/10.1016/j.chemgeo.2019.04.020.

Reimann, C., Birke, M., Demetriades, A., Filzmoser, P., O'Connor, P. 2014a. Chemistry of Europe's Agricultural Soils, Part A: Methodology and Interpretation of the GEMAS Dataset. Geologisches Jahrbuch (Reihe B). Schweizerbarth, Stuttgart, 528 p.

Reimann, C., Birke, M., Demetriades, A., Filzmoser, P., O'Connor, P. 2014b. Chemistry of Europe's

Agricultural Soils-Part B: General Background Information and Further Analysis of the GEMAS Dataset. Geologisches Jahrbuch (Reihe B). Schweizerbarth, Stuttgart, 352 p.

Rudnick, R.L., Tomascak, P.B., Njo, H.B., Gardner, L.R. 2004. Extreme lithium isotopic fractionation during continental weathering revealed in saprolites from South Carolina. Chem. Geol., 212, 45-57.

Ryu, J.S., Vigier, N., Lee, S.W., Lee, K.S. Chadwick, O.A. 2014. Variation of lithium isotope geochemistry during basalt weathering and secondary mineral transformations in Hawaii. Geochim. Cosmochim. Acta, 145, 103-115.

Sequeira Braga, M.A., Lopes Nunes, J.E., Paquet, H., Millot, G. 1990. Climatic zonality of coarse 772 granitic saprolites ("arènes") in Atlantic Europe from Scandinavia to Portugal. Sciences Géologiques, Bulletins et Mémoires, 85, 99-108.

Sequeira Braga, M.S., Paquet, H., Begonha, A. 2002. Weathering of granites in a temperate climate (NW Portugal): Granitic saprolites and arenization. Catena, 49, 41-56.

Sarazin, G., 1979. Géochimie de l'aluminium au cours de l'altération des granites et basaltes sous climat tempéré. Doctoral thesis, University of Paris VI, 169 p.

Shouakar-Stash, O., Kharaka, Y., Koopmann, R., Harmon, R., Négrel, Ph., Wanty, R.B. 2018. A remembrance of Thomas (Tom) Bullen, 1951-2018. Appl. Geochem., 98, 474-475.

Stallard, R.F., Edmond, J.M. 1981. Geochemistry of the Amazon: 1. Precipitation chemistry and the marine contribution to the dissolved load at the time of peak discharge. J. Geophys. Res.: Oceans, 86(C10), 9844-9858.

Sullivan, P.L., Ma, L., West, N., Jin, L., Karwan, D.L., Noireaux, J., Steinhoefel, G., Gaines, K.P., Eissenstat, D.M., Gaillardet, J., Derry L.A., Meek, K., Hynek S., Brantley S.L. 2016. CZ-tope at 

processes across timescales in a temperate forested landscape. Chem. Geol., 445, 103-119.

Tsai, P.H., You, C.F., Huang, K.F., Chung, C. H., Sun, Y.B. 2014. Lithium distribution and isotopic fractionation during chemical weathering and soil formation in a loess profile. J. Asian Earth Sci., 87, 1-10.

Tomascak, P.B. 2004. Developments in the understanding and application of lithium isotopes in the earth and planetary sciences. Rev. Mineral. Geochem., 55, 153-195.

Vázquez M., Ramírez S., Morata D., Reich M., Braun J.J., Carretier S. 2016. Regolith production and chemical weathering of granitic rocks in central Chile. Chem. Geol., 446, 87-98.

Velbel, M.A. 1988. Weathering and soil-forming processes. In: Forest Hydrology and Ecology at Coweeta. Springer, New York, NY, 93-102.

Vigier, N., Decarreau, A., Millot, R., Carignan, J., Petit, S. France-Lanord, C. 2008. Quantifying Li isotope fractionation during smectite formation and implications for the $\mathrm{Li}$ cycle. Geochim. Cosmochim. Acta, 72, 780-792.

Vigier, N., Gislason, S.R., Burton, K.W., Millot, R., Mokadem, F. 2009. The relationship between riverine lithium isotope composition and silicate weathering rates in Iceland. Earth Planet. Sci. Lett., $287,434-441$.

803

Wanner, C., Bucher, K. Pogge von Strandmann P.A.E., Waber, H.N. Pettke T. 2017. On the use of Li isotopes as a proxy for water-rock interaction in fractured crystalline rocks: A case study from the Gotthard rail base tunnel. Geochim. Cosmochim. Acta, 198, 396-418.

Wang, Q.L., Chetelat, B., Zhao, Z.Q., Ding, H., Li, S.L., Wang, B.L., Li, J., Liu, X.L. 2015. Behavior of lithium isotopes in the Changjiang River system: Sources effects and response to weathering and erosion. Geochim. Cosmochim. Acta, 151, 117-132.

Weynell, M., Wiechert, U., Schuessler, J.A. 2017. Lithium isotopes and implications on chemical weathering in the catchment of Lake Donggi Cona, northeastern Tibetan Plateau. Geochim. Cosmochim. Acta, 213, 155-177.

White, A.F., Blum, A.E. 1995. Effects of climate on chemical weathering in watersheds. Geochim.

813 Wimpenny, J., Gislason, S.R., James, R.H., Gannoun, A., Pogge von Strandmann, P.A.E, Burton, K.W.

814 2010. The behaviour of $\mathrm{Li}$ and $\mathrm{Mg}$ isotopes during primary phase dissolution and secondary mineral formation in basalt. Geochim. Cosmochim. Acta, 74, 5259-5279.

816 You, C.F., Chan, L.H. 1996. Precise determination of lithium isotopic composition in low concentration natural samples. Geochim. Cosmochim. Acta, 60, 909-915. 


\begin{tabular}{cccc} 
Sample & Ref. & $\begin{array}{c}\mathrm{Li} \\
\mu \mathrm{gg}-1\end{array}$ & $\delta 7 \mathrm{Li}$ \\
\hline M1/POU & Whole rock & 143.1 & -1.9 \\
ALT1 & Mazel grit & 104.7 & -3.4 \\
& & & \\
$\mathrm{Ap}$ & Apatite & 13.3 & 0.0 \\
$\mathrm{PI}$ & Plagioclase & 20.9 & -1.7 \\
$\mathrm{Bi}$ & Biotite & 489.1 & 0.8 \\
$\mathrm{KF}$ & K-Feldspar & 5.3 & -2.6 \\
& & & \\
D19-3/A0 & A0 & 56.2 & 0.1 \\
D19-3/A1 & A1 & 68.8 & -2.1 \\
D19-3/A2 & A2 & 110.9 & -3.4 \\
D17-3/B0 & B0 & 60.6 & 3.3 \\
D17-3/B1 & B1 & 61.6 & 0.0 \\
D17-3/B2 & B2 & 66.2 & -2.7 \\
& & &
\end{tabular}

\begin{tabular}{ccc} 
Sample & $\begin{array}{c}\mathrm{Li} \\
\mu \mathrm{mol} \mathrm{L-1}\end{array}$ & $\delta 7 \mathrm{Li}$ \\
\hline Spring waters & & $\delta 7 \mathrm{Li}$ \\
Mazel & 551 & 5.0 \\
FB1 & 424 & 4.9 \\
Ranc1 & 158 & 3.8 \\
Ranc2 & 397 & 2.6 \\
Surface waters & & \\
D10' & 0.22 & 12.7 \\
D8 & 0.15 & 9.2 \\
D11 & 0.23 & 12.1 \\
D9bis & 0.16 & 10.0 \\
D9' & 0.21 & 10.7 \\
D11' & 0.24 & 13.0
\end{tabular}

